\title{
CANDIDOSE ASSOCIADA AO USO DE PRÓTESE TOTAL SUPERIOR: AVALIAÇÃO DEMOGRÁFICA, CLÍNICA E MICROSCÓPICA
}

\section{Erika Martins Pereira}

Dissertação apresentada à Faculdade de Odontologia de Bauru, Universidade de São Paulo, como parte dos requisitos para a obtenção do título de Mestre em Odontologia, área de concentração Patologia Bucal. 


\section{CANDIDOSE ASSOCIADA AO USO DE PRÓTESE TOTAL SUPERIOR: AVALIAÇÃO DEMOGRÁFICA, CLÍNICA E MICROSCÓPICA}

\section{Erika Martins Pereira}

Dissertação apresentada à Faculdade de Odontologia de Bauru, Universidade de São Paulo, como parte dos requisitos para a obtenção do título de Mestre em Odontologia, área de concentração Patologia Bucal.

Orientadora: Prof ${ }^{a}$. Dra. Vanessa Soares Lara 


\section{PEREIRA, ERIKA MARTINS}

P414c Candidose associada ao uso de prótese total superior: avaliação demográfica, clínica e microscópica / Erika Martins Pereira - Bauru, 2007.

$115 f .: 30 \mathrm{~cm}$.

Dissertação (Mestrado) Faculdade de Odontologia de Bauru.

Orientadora: Profa. Dra. Vanessa Soares Lara

Data de aprovação pelo Comitê de Ética em Pesquisa da Faculdade de Odontologia de Bauru - USP: 29 de Novembro de 2006. Processo $n^{\circ}$ $118 / 2006$

A cópia do parecer de aprovação encontra-se no capitulo "Anexo".

Autorizo, exclusivamente para fins acadêmicos e científicos, a reprodução total ou parcial desta dissertação, por processos fotocopiadores e outros meios eletrônicos.

\section{ASSINATURA}

Bauru, de de 2007 



\section{Erika Martins Pereira}

29 de abril de 1978

Belém - PA

Vitor Mauricio Gouvêa Pereira

Waltair Maria Martins Pereira

$1998-2003$

2003-2005

2005-2007
Nascimento

Filiação

Curso de Odontologia - Universidade Federal do Pará (UFPA).

Curso de Especialização em Periodontia - Sociedade de Promoção Social do Fissurado Lábio Palatal (PROFIS).

Programa de Pós-Graduação em Mestrado em Odontologia, Área de Concentração Patologia Bucal, na Faculdade de Odontologia de Bauru Universidade de São Paulo. 
"Cada um que passa em nossa vida, passa sozinho, pois cada pessoa é única e nenhuma substitui outra.

Cada um que passa em nossa vida, passa sozinho, mas não vai só nem nos deixa sós.

Leva um pouco de nós mesmos, deixa um pouco de si mesmo. Há os que levam muito, mas há os que não levam nada. Essa é a maior responsabilidade de nossa vida, e a prova de que duas almas não se encontram ao acaso."

Antoine de Saint-Exupéry 
Dedico este trabalho as pessoas mais importantes da minha vida: Waltair Maria Martins Pereira e Vitor Mauricio Gouvêa Pereira.

" Vocês deixaram seus sonhos para que eu sonhasse. Derramaram lágrimas para que eu fosse feliz. Vocês perderam noites de sono para que eu dormisse tranquiila. Acreditaram em mim, apesar de meus erros e de muitas vezes nem eu mesma acreditar. Escolheram-me para viver "essa vida" com vocês.

Jamais esqueçam que eu levarei para sempre um pedaço de vocês dentro do meu próprio ser..." 


\section{AGRADECIMENTOS PESSOAIS}

À minha orientadora Profa. Dra. Vanessa Soares Lara, pela dedicação, pelos conselhos e por todos os momentos, bons e difíceis, que me fizeram aprender a valorizar muito a vida;

Ao Prof. Dr. Alberto Consolaro, pelo conhecimento e carinho;

Ao Prof. Dr. Luís Antônio de Assis Taveira, pelos ensinamentos de vida. Quero ser como você quando "crescer"!!!!!

À Profa. Dra. Denise Tostes Oliveira, pelos conselhos profissionais $e$ pessoais. Você é um grande exemplo de profissional, mulher e mãe;

Aos colegas, amigos funcionários e ex-funcionários da Disciplina de Patologia Bucal: Fátima Aparecida Silveira, Maria Cristina Carrara Felipe, Luís Fernando Bernardi, Valdir João Afonso, Osiel Pereira Cabrera e Rodrigo Alves, pelo carinho e disponibilidade com que sempre me auxiliaram;

À Rosário, que em muitos momentos foi minha luz com conselhos e ensinamentos de patologia;

Aos colegas que conheci na Patologia: Patrícia, Gisele, Roberta, Milton, Michele, Leda, Renata Consolaro, Renata Falchete, Camila, Tiago, Bethânia, Luciana, Erick, Suzana, Marta, e Sylvie e aos colegas de turma de mestrado: Carlos, Érika Sinara, Janaína e Simone, pelos momentos de carinho que passamos juntos:

Aos colegas da Microbiologia e Imunologia: Profa. Dra. Ana Paula Campanelli, Thaís, Valéria, Tatiana, Eduardo, Dalva e André pela colaboração no meu aprendizado;

Aos funcionários da Pós-Graduação: Ana Letícia Palombo Momesso, Giane Tenório Quintela e Maria Margareth Pereira MoKarzel, pela ajuda.

Aos meus pais, Waltair e Vitor e ao meu irmão André, que mudaram muitas vezes suas vidas, abrindo mão de sonhos e lutando sempre para que eu pudesse realizar meus sonhos. Muito obrigada, vocês são minha vida!!!!!!! 
À minha segunda casa, minha segunda família, Walnize, Paulo, Héron e Caio tenham a certeza que vocês fizeram meus dias passarem com uma quantidade menor de tristeza;

À minha princesa Anna Paula, que mesmo sem saber, mudou muitas vezes "minhas chatices" para uma alegria enorme. Obrigada, você é uma maravilha!!!;

À minha mãe bauruense Ivânia, por me mostrar muitas maneiras de viver, de lutar e aceitar as mudanças da vida. Você é muito especial!!!!

Aos amigos verdadeiros Otávia, Raphael, Malu e Marcus, que sempre estiveram do meu lado, mesmo que muitas vezes eu imaginasse o contrário. Obrigada por me amarem assim!!!!!

À super amiga Ana Carolina Cuzzuol Fracalossi, tenha certeza que essa amizade é para muitas vidas. Obrigada por todos os momentos de apoio e carinho. Diego, obrigada por ter-me "emprestado" um pedacinho da sua Carol;

À minha amiga e companheira Karen, nunca imaginei que seríamos assim. Você me ensinou como ficar só, lutar, amadurecer e como aceitar e respeitar as diferenças. Não tenho como agradecer tudo que você fez por $\operatorname{mim} . .$.

À minha Melaine, você além de irmã, foi minha mãe em muitos momentos, tive de você conselhos, carinho, sabedoria e amor como nunca imaginei encontrar longe de casa. Tenha certeza que uma grande parte do que sou hoje devo a você. Te amo!!!!!! 


\section{AGRADECIMENTOS INSTITUCIONAIS}

À Coordenação de Aperfeiçoamento de Pessoal de Nível Superior (CAPES), pela concessão da bolsa de mestrado e pela possibilidade de se obter financiamento via Programa de Apoio a Pós-Graduação (PROAP);

À Faculdade de Odontologia de Bauru, Universidade de São Paulo, na pessoa de seu excelentíssimo Diretor Prof. Dr. Luiz Fernando Pegoraro;

À comissão de Pós-Graduação da Faculdade de Odontologia de Bauru, na pessoa do presidente Prof. Dr. José Carlos Pereira;

Ao Departamento de Estomatologia, da Faculdade de Odontologia de Bauru, na pessoa do chefe Prof. Dr. Luiz Eduardo Montenegro Chinellato. 


\section{SUMÁRIO}

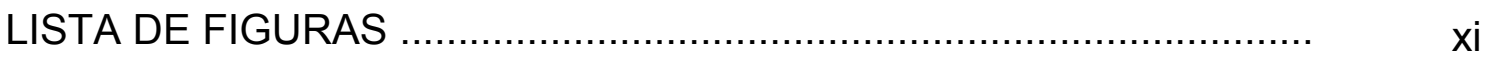

RESUMO

1-INTRODUÇÃO E SÍNTESE BIBLIOGRÁFICA ............................... 3

1. 1. Considerações gerais..................................................... 3

1. 2. Candida albicans e patologias bucais relacionadas.................... 6

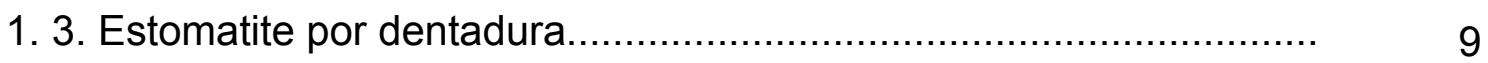

1. 3.1. Características clínicas e fatores predisponentes..................... 9

1. 3.2. Aspectos imunológicos.................................................... 14

1. 3.3. Características microscópicas e diagnóstico.......................... 16

1. 4. Caracterização da mucosa normal do palato............................. 17

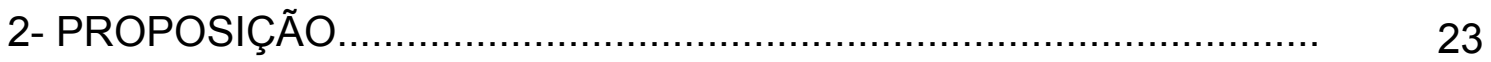

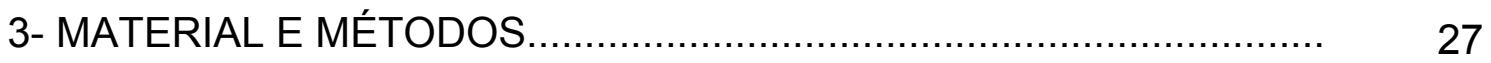

3.1. Obtenção, seleção e caracterização demográfica, clínica e microscópica da amostragem............................................... 27

3.2. Técnicas de coloração especial para detecção de fungo................. 30

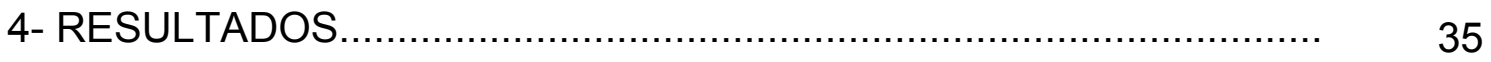

4.1. Caracterização demográfica e clínica da amostragem................... 35

4.1.1. Mucosa normal de palato.............................................. $\quad 35$

4.1.2. Estomatite por dentadura atrófica...................................... 35

4.1.3. Hiperplasia fibrosa inflamatória associada à candidose.............. 36

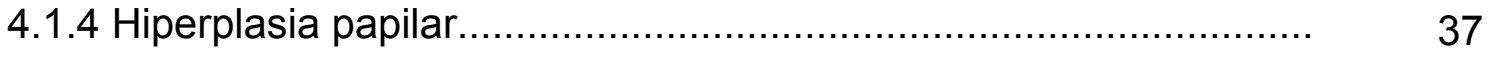

4.2. Caracterização microscópica da amostragem............................ 44

4.2.1. Mucosa normal de palato............................................... 44

4.2.2. Estomatite por dentadura atrófica...................................... 45

4.2.3. Hiperplasia fibrosa inflamatória associada à candidose.............. 46

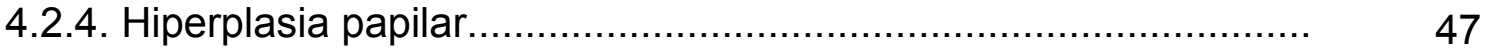


5- DISCUSSÃO.

6- CONCLUSÃOO

ANEXO...

REFERÊNCIAS BIBLIOGRÁFICAS. 86 ABSTRACT. 96 


\section{LISTA DE FIGURAS}

\section{FIGURAS}

Figura 1 Número de pessoas (em milhões) no Brasil com 60 anos ou mais, do ano 1980 ao ano 2020 (IBGE/2006).

Figura 2 Em A, nota-se candidose crônica atrófica associada ao uso de prótese total superior (tipo I) e, em B, hiperplasia papilar associada ao uso de prótese total superior (tipo III).

(A - caso clínico gentilmente cedido pelo Prof. Dr. Vinicius Carvalho Porto, do Departamento de Prótese, FOB - USP).......

Figura 3 Mucosa bucal normal. Em A, nota-se área de revestimento epitelial com acantose, ausência de queratina e tecido conjuntivo fibroso subjacente com discreto infiltrado inflamatório mononuclear. Em B, observa-se área de revestimento epitelial com acantose, cristas e ortoqueratose (A e B: H.E.; aumentos originais de $25 x$ ).

Figura 4 Estomatite por dentadura atrófica. Cristas epiteliais alongadas e em forma de tubo de ensaio e, no tecido conjuntivo fibroso subjacente, nota-se discreto infiltrado inflamatório mononuclear na região de lâmina própria $(A)$. $E m B$, no tecido conjuntivo fibroso subepitelial, observa-se hiperplasia pseudoepiteliomatosa (A e B: H.E.; aumentos originais de $25 x$ )...

Figura 5 Estomatite por dentadura atrófica. Em A, nota-se revestimento epitelial com ausência da camada de queratina e, em $B$, a presença de microabscessos de Munro (A e B: H.E; aumentos originais de $100 x-A$, e $250 x-B)$.

Figura 6 Hiperplasia papilar. Nota-se revestimento epitelial com áreas de hiperplasia (•) e com projeção papilar (A). Em B, observam-se crista epitelial de aspecto bífido e, no tecido conjuntivo fibroso subjacente, moderado infiltrado inflamatório mononuclear em lâmina própria e região perivascular ( $A$ e $B$ : H.E; aumentos originais de $25 x$ ) 
Figura 7 Hiperplasia papilar. Em A, no tecido epitelial, notam-se reação liquenóide e discreta exocitose, e em $B$, microabscesso de Munro (círculo azul) (A e B: H.E; aumentos originais de 100x $A$, e 250x - B)

Figura 8 Hiperplasia papilar. Em A, nota-se tecido conjuntivo fibroso com infiltrado inflamatório mononuclear perivascular (círculo em amarelo). Em B, observa-se pérola córnea-like (círculo em amarelo) circundada por intenso infiltrado inflamatório mononuclear (A e B: H.E; aumentos originais de $100 x)$ 


\section{QUADROS}

Quadro 1 Caracterização demográfica dos indivíduos submetidos a biópsias de lesões com mucosa normal de palato. As respectivas lâminas foram obtidas dos arquivos da Disciplina de Patologia do Departamento de Estomatologia da Faculdade de Odontologia de Bauru USP

Quadro 2 Caracterização demográfica dos indivíduos portadores e clínica das amostras de lesões de candidose em região superior de boca, obtidas dos arquivos da Disciplina de Patologia do Departamento de Estomatologia da Faculdade de Odontologia de Bauru USP

Quadro 3 Caracterização clínica das amostras de lesões de candidose em região superior de boca, obtidas dos arquivos da Disciplina de Patologia do Departamento de Estomatologia da Faculdade de Odontologia de Bauru USP

Quadro 4 Caracterização microscópica das amostras de mucosa normal de palato, obtidas dos arquivos da Disciplina de Patologia do Departamento de Estomatologia da Faculdade de Odontologia de Bauru - USP

Quadro 5 Caracterização microscópica das amostras de mucosa normal de palato, obtidas dos arquivos da Disciplina de Patologia do Departamento de Estomatologia da Faculdade de Odontologia de Bauru - USP

Quadro 6 Caracterização microscópica das amostras de lesões de candidose em região superior de boca, obtidas dos arquivos da Disciplina de Patologia do Departamento de Estomatologia da Faculdade de Odontologia de Bauru USP 
Quadro 7 Caracterização microscópica das amostras de lesões de candidose em região superior de boca, obtidas dos arquivos da Disciplina de Patologia do Departamento de Estomatologia da Faculdade de Odontologia de Bauru USP

Quadro 8 Caracterização microscópica das amostras de lesões de candidose em região superior de boca, obtidas dos arquivos da Disciplina de Patologia do Departamento de Estomatologia da Faculdade de Odontologia de Bauru USP 


\section{RESUMO}

A estomatite por dentadura representa um processo inflamatório na mucosa oral em contato com a resina acrílica da prótese total ou parcial removível, sendo sua etiologia multifatorial, associada com fatores locais e sistêmicos, incluindo a presença de Candida albicans. O presente trabalho teve como objetivo a realização de uma análise demográfica, clínica e microscópica da candidose, associada ao uso da prótese total superior, nas formas atrófica, hiperplásica papilar e associada à hiperplasia fibrosa inflamatória. Para este fim, as amostras dos arquivos do laboratório de Anatomia Patológica do Departamento de Estomatologia - Área de Patologia - da Faculdade de Odontologia de Bauru, da Universidade de São Paulo, foram avaliadas microscopicamente, por meio das colorações de Hematoxilina e Eosina, Grocott de prata e Periodic Acid Schiffer (PAS), em comparação à mucosa normal de palato, oriunda de pacientes não usuários de prótese total ou removível superior. Foram resgatadas todas as informações contidas nas fichas clínicas correspondentes às amostras. As amostras de candidose bucal, independente do grupo, foram provenientes principalmente de indivíduos idosos, com médias variando de 51 a 60 anos, do gênero feminino e raça branca. Em alguns casos, o diagnóstico clínico da estomatite por dentadura atrófica pode ser difícil, necessitando de biópsia para confirmação. As lesões de hiperplasia papilar são removidas cirurgicamente com mais freqüência que aquelas de estomatite por dentadura atrófica, sendo geralmente reconhecidas pelo profissional clínico como hiperplasia fibrosa inflamatória. A candidose nas hiperplasias fibrosas inflamatórias não apresenta sinais clínicos exclusivos da sua presença; assim, torna-se improvável a suspeita clínica desta associação. De forma diferente da mucosa normal, microscopicamente, na maioria dos casos de candidose bucal, observaram-se revestimento epitelial hiperplásico com cristas alongadas, algumas em forma de tubo de ensaio, com freqüentes áreas de ausência de queratina, pequenos focos de reação liquenóide e de microabscessos, bem como extensas áreas de hiperplasia pseudoepiteliomatosa. Somente a hiperplasia papilar apresentou cristas epiteliais bífidas, revelando ainda maior freqüência de pérolas córneas-like e 
cristas em forma de tubo de ensaio, quando comparada com as outras formas de candidose bucal. $O$ tecido conjuntivo fibroso subjacente, na candidose bucal, revelou intenso a moderado infiltrado inflamatório mononuclear predominante na lâmina própria e região perivascular. Não se observou marcação fúngica por meio das colorações especiais Grocott de prata e PAS. Assim, o diagnóstico microscópico da candidose bucal não deve depender da visualização do fungo nas camadas mais superficiais do revestimento epitelial.

Palavras-chaves: candidose, prótese total superior, estomatite por dentadura. 
INTRODUÇÃO E SÍNTESE BIBLIOGRÁFICA 



\section{INTRODUÇÃO E SÍNTESE BIBLIOGRÁFICA}

\subsection{CONSIDERAÇÕES GERAIS}

Uma das mudanças mais significativas no terceiro milênio é o aumento da expectativa de vida dos seres humanos. O crescimento da população idosa é um fenômeno que ocorre não só nos países desenvolvidos, mas também se verifica, nos países em desenvolvimento. A expectativa de vida ao nascer, no Brasil, aumentou progressivamente no século $X X$. No início daquele século, o brasileiro tinha uma expectativa de vida de menos de 35 anos. No final do século XX, a expectativa de vida era para mais de 70 anos. ${ }^{44}$

Certamente, este fato surge como resultado de grandes avanços tanto na ciência quanto nas questões de saneamento básico, na conscientização de higiene e de alimentação que abrangem, principalmente, a população de países mais desenvolvidos do ponto de vista cultural e econômico. ${ }^{44}$

Cada vez mais o tema do envelhecimento vem sendo abordado, em todos os países. No Brasil, o envelhecimento da população é um fenômeno relativamente recente e os estudos sobre o tema não são numerosos. Porém, os poucos existentes têm demonstrado que o processo de envelhecimento da população brasileira é considerado irreversível - pela diminuição da natalidade e aumento da expectativa de vida de sua população. Segundo o último levantamento epidemiológico da população brasileira, existem 11.864 .773 idosos com 60 anos ou mais, conforme pode ser visto na Figura $1 .{ }^{45}$ 


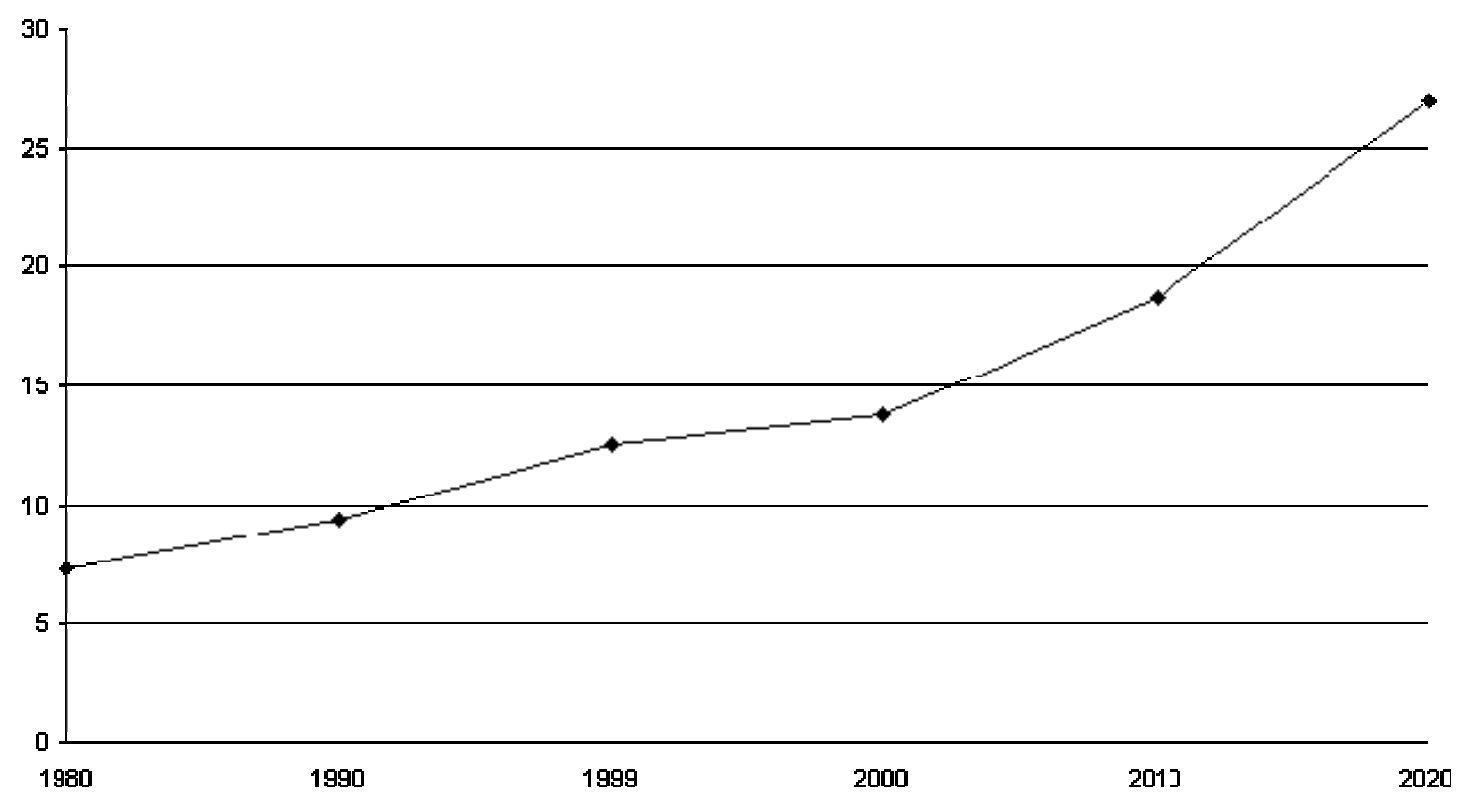

FIGURA 1. Número de pessoas (em milhões) no Brasil com 60 anos ou mais, do ano 1980 ao ano 2020 (IBGE/2006).

Os gastos com a saúde dos idosos também têm aumentado com o aumento da expectativa de vida. Assim, estudos estão sendo feitos visando melhorar a qualidade de vida destas pessoas. Isto tem gerado o aparecimento de novas áreas de pesquisa dentro da Medicina, Odontologia e suas subáreas.

Considerando Odontologia e indivíduos idosos, o último levantamento epidemiológico de saúde bucal da população brasileira, ocorrido em 2002-3 e conhecido como SB Brasil 2003 (Condições de saúde bucal da população brasileira), revelou que 3093 idosos são usuários de prótese total superior. Esse fato indica que a saúde bucal não constituiu uma prioridade em saúde pública, revelando baixa disponibilidade, à população, de ações preventivas, educativas e curativas. ${ }^{18,28,40,42,45,57}$

Sob o ponto de vista epidemiológico, a condição de saúde bucal da população idosa é visualizada a partir de dados internacionais de pesquisas realizadas em diversos países, que apontam para a sua real precariedade. Assim, em estudo epidemiológico realizado em um hospital de longa permanência, em Helsinki, Finlândia, foi observado que $42 \%$ dos idosos examinados eram edêntulos. Do total de dentados, $37 \%$ necessitavam de restaurações, $51 \%$ de terapia periodontal e $42 \%$ de extrações dentárias. ${ }^{29} \mathrm{Em}$ idosos residentes em instituições na cidade de Berlim, Alemanha, em $80 \%$ dos pacientes o tratamento odontológico era 
necessário e apenas $37,6 \%$ das próteses apresentavam retenção e estabilidade adequadas. $^{28}$

No Brasil, as pesquisas até então realizadas também indicam a precariedade da situação de saúde bucal dos idosos que residem em instituições próprias para este segmento populacional. Na região Sul, em pesquisa realizada no município de Curitiba, PR, dos idosos asilados estudados, 56 eram edêntulos totais; destes $79 \%$ faziam uso de pelo menos uma prótese total e $21 \%$ não usavam nenhum tipo de prótese; observou-se, também, ainda que em percentual pequeno, a existência de idosos edêntulos parciais. ${ }^{28}$

$\mathrm{Na}$ Região Sudeste, no Estado de São Paulo, nos municípios de Araçatuba e Araraquara assim como no Estado do Rio de Janeiro, no município do Rio de Janeiro, as pesquisas também enfocam a precariedade da saúde bucal dos idosos. Em Araçatuba, após estudo epidemiológico com idosos residentes em instituições próprias para este segmento populacional, foi observado que $69 \%$ do total dos idosos eram desdentados totais, sendo que, destes, 52\% não usavam prótese e $48 \%$ eram portadores de prótese total. ${ }^{28} \mathrm{Em}$ Araraquara, dos idosos residentes em instituições próprias, foi observado que $72 \%$ eram edêntulos e que $61 \%$ dos examinados necessitavam de prótese $^{28}$; já no município do Rio de Janeiro, $29,1 \%$ dos idosos examinados usavam ou necessitavam de pelo menos uma prótese total. $^{28}$

Esse cenário não muda quando o foco passa a ser a Região Nordeste do país, visto que após estudo realizado em uma instituição filantrópica na cidade de Fortaleza, CE, constatou-se que, em uma população de 160 idosos, 58,1\% eram totalmente desdentados, e que $84,4 \%$ deles necessitavam de algum tipo de prótese superior, assim como $88,7 \%$ precisavam de prótese inferior. Foi observado também, nesse mesmo estudo, que $28,8 \%$ dos idosos investigados usavam prótese total superior e $16,9 \%$ prótese total inferior. ${ }^{28}$

Pacientes usuários de prótese, principalmente total superior e em especial os indivíduos idosos, comumente apresentam infecção por Candida, causando assim a patologia denominada estomatite por dentadura, que na maioria dos casos não é corretamente diagnosticada pelo clínico, tornando-se assim uma complicação e um problema grave para estes pacientes. ${ }^{19,24,37}$ 


\subsection{CANDIDA ALBICANS E PATOLOGIAS BUCAIS RELACIONADAS}

Os fungos pertencentes ao gênero Candida são encontrados em diversos ecossistemas, como florestas, rios e solos e constituem organismos comensais, comuns da microbiota de hospedeiros humanos e animais; entretanto, sob determinadas condições, comportam-se como patógenos oportunistas, produzindo infecções que vão desde lesões superficiais da pele e mucosas até disseminações sistêmicas graves e invasivas. ${ }^{30}$

A boca é uma porta de entrada para vários microorganismos, entre estes, a Candida, que desde os tempos de Hipócrates pode resultar em uma das maiores infecções micóticas da cavidade bucal, apresentando-se como lesões superficiais nas mucosas. ${ }^{58}$

A espécie Candida albicans (C.albicans) é um fungo dimórfico, gram positivo, apresentando-se como blastosporos (leveduras) e formas miceliais (hifas) que fazem parte da microbiota bucal normal, em 20 a $60 \%$ da população em geral. ${ }^{42,58} \mathrm{Em}$ algumas situações, apresenta-se como um fungo trimórfico, principalmente quando colocado em certos meios de cultura especializados como 0 ágar farinha de milho, formando-se pequenos esporos altamente refringentes chamados clamidosporos. A função exata dos clamidosporos é ainda desconhecida e eles não são encontrados na cavidade oral, mais são úteis para a identificação laboratorial de Candida albicans. Existe ainda um considerável debate sobre a patogenicidade das leveduras e das hifas de Candida albicans e a importância biológica e clínica da transição entre as duas formas. ${ }^{42,46,58}$ Consistentemente é sugerido que a transição da levedura para hifa, frequentemente chamada de transformação de $L$ para $M$, é sinônimo de mudança de um estado comensal para patogênico. Não há duvida de que um número aumentado de hifas é encontrado nas infecções orais produzidas por Candida albicans; no entanto, elas também podem ser vistas em cavidades bucais saudáveis. ${ }^{42}$

As leveduras de $C$. albicans são ovais medindo de 2 a 14 micrômetros e reproduzem por brotamento. As hifas são estruturas filamentosas que crescem por alongamento, sendo o tipo morfológico responsável pela infecção inicial. ${ }^{46,58} \mathrm{Em}$ geral, a transformação de leveduras para hifas é importante, mas nem sempre é um pré-requisito para ocorrer a infecção. As hifas penetram os tecidos orais, mas curiosamente só invadem as camadas de queratina e granular do epitélio, nunca a 
espessura total. Em biópsia de tecidos, as hifas invadem abruptamente a superfície do epitélio em ângulo reto em relação ao longo eixo da célula epitelial. ${ }^{42}$

Os termos candidose e candidíase são utilizados na literatura para denominar infecção bucal por fungos, especialmente pela Candida albicans. Alguns pesquisadores preferem o termo candidose em razão do sufixo ose ser geralmente utilizado na denominação de outras infecções fúngicas, como a paracococidioidomicose. O sufixo íase é menos apropriado porque geralmente reflete uma infecção por protozoários, como a giardíase. No entanto, candidíase é um termo comumente empregado e amplamente sedimentado. ${ }^{38}$

A candidose ou candidíase originalmente representava doenças causadas por C. albicans, entretanto, existem outras espécies de Candida que estão ocasionalmente envolvidas, como C. tropicalis, C. glabrata, C. krusei, C. parapsilosis, C. kefyr, C. guilliermondii e C. Iusitanae. ${ }^{58}$

Os sítios bucais mais freqüentes e densamente colonizados, por Candida albicans, foram, para os dentados, a língua, o palato e a mucosa jugal; nos portadores de próteses, totais e removíveis com base de acrílico, foram a língua e as superfícies protéticas superiores e inferiores. ${ }^{30}$ Os trabalhos afirmam existir uma associação estatisticamente significante entre a presença de leveduras de $C$. albicans na cavidade bucal e o uso de próteses totais. ${ }^{30}$ Existem pesquisas que afirmam que as próteses totais superiores com rugosidade superficial podem favorecer a implantação de leveduras pela criação de um microambiente com pH baixo no espaço entre a prótese e a mucosa do palato. Com isso, a mucosa do palato fica protegida da ação química da saliva e da remoção de microorganismos pelo fluxo salivar ${ }^{30}$, porém contrapondo estas afirmativas, Kulakl-Ozkan et al. ${ }^{36}$ (2002) não observaram relação entre o uso de próteses totais ou parciais e o aumento da ocorrência ou da proporção desses fungos na mucosa bucal.

Geralmente, o invasor Candida albicans não chega a causar doença, podendo ser diluído na saliva e levado com ela para o trato gastrintestinal, ou ainda viver de forma harmônica com os tecidos bucais. Entretanto, se não houver resposta imune satisfatória no local da infecção, o fungo pode se disseminar para os tratos respiratório e gastrointestinal, levando a candidose. ${ }^{19,24,37}$

A candidose bucal, que acomete a população, é classificada clinica e microscopicamente como $^{5,25,26,38,42,46,48,58}$ : 
Candidose aguda pseudomembranosa: caracteriza-se por placas branco-amareladas por todas as regiões da cavidade bucal que desaparecem à raspagem. Microscopicamente, observa-se material necrótico e células epiteliais descamadas invadidas por leveduras e hifas de Candida, assim como por células polimorfonucleares. Podem ser observados ainda microabscessos na superfície epitelial. O epitélio apresenta-se com acantose e a resposta inflamatória no tecido conjuntivo fibroso compreende linfócitos, plasmócitos e polimorfonucleares.

Candidose aguda atrófica: caracteriza-se por áreas eritematosas mais comumente no dorso da língua, palato e mucosa jugal. Microscopicamente, nota-se presença de hifas e neutrófilos penetrando no epitélio. No tecido conjuntivo fibroso, observam-se linfócitos, plasmócitos e polimorfonucleares responsáveis pela reação inflamatória.

Candidose crônica hiperplásica: caracteriza-se por placas brancas em todas as regiões da cavidade bucal, que não pode ser removida com procedimento de raspagem. A idade média dos pacientes acometidos por esta patologia foi de 61 anos. Microscopicamente, observa-se epitélio hiperplásico paraqueratinizado com presença de invasão por Candida na superfície. No tecido conjuntivo fibroso subjacente, nota-se escasso infiltrado inflamatório crônico.

Glossite romboidal média: caracteriza-se por lesão com uma área central bem demarcada, não ulcerada, forma rombóide, áspera ou lisa, levemente endurecida, de coloração rosa ou vermelha no terço médio do dorso da língua, destituídos de papila e com discreta sintomatologia. O tamanho costuma variar de 0,5 a $2 \mathrm{~cm}$, e apresenta-se anterior à área das papilas circunvaladas. Microscopicamente, nota-se epitélio hiperplásico paraqueratinizado, com cristas invadindo o tecido conjuntivo que se fundem entre si, com hifas e microabscessos na superfície. No tecido conjuntivo fibroso subjacente, é perceptível infiltrado inflamatório crônico subepitelial.

Queilite angular: caracteriza-se por lesões fissuradas e eritematosas no ângulo da boca. Microscopicamente, observa-se presença de hifas e neutrófilos penetrando no epitélio; no tecido conjuntivo fibroso observam-se linfócitos, plasmócitos e polimorfonucleares responsáveis pela reação inflamatória.

Pode ocorrer em qualquer idade, porém é associada a pessoas idosas, que usam prótese com falha na adaptação, que determina dobras nos ângulos da boca. Normalmente, é concomitante a ela uma candidose crônica abaixo da prótese. 
Estomatite por dentadura ou candidose crônica atrófica: caracterizase por lesões avermelhadas geralmente no palato duro sob o acrílico que serve como base das próteses totais ou parciais, geralmente superiores. Microscopicamente, observa-se epitélio pavimentoso estratificado com exocitose e, no tecido conjuntivo fibroso subjacente, nota-se infiltrado inflamatório mono e polimorfonuclear.

Embora o tecido apresente-se hiperêmico com sinais de inflamação, este tipo de candidose é frequentemente assintomática, podendo ser observada mucosa hemorrágica e, em alguns casos, o paciente refere prurido, queimação, sintomatologia dolorosa, sabor desagradável e pode apresentar ainda halitose.

Outra lesão relacionada com o uso de prótese total é a hiperplasia fibrosa inflamatória, que é uma resposta reacional, reversível ou não, caracterizada pelo aumento da atividade dos fibroblastos, resultando em aumento de volume. ${ }^{14}$ Esta lesão caracteriza-se por tecido hiperplásico normalmente relacionado às margens das próteses totais mal adaptadas. Microscopicamente, nota-se epitélio hiperplásico ora paraqueratinizado ora ortoqueratinizado; no tecido conjuntivo fibroso subjacente, nota-se variado infiltrado inflamatório mononuclear. Em alguns casos, essa lesão está associada a algum tipo de candidose e, neste caso, pode-se observar um infiltrado mais intenso subepitelial e hifas na superfície epitelial. ${ }^{19,57}$

\subsection{ESTOMATITE POR DENTADURA}

O termo estomatite por dentadura é usado para descrever um processo inflamatório na mucosa oral em contato com o acrílico da prótese total ou parcial removíveis ${ }^{8,11,13,26}$, sendo sua etiologia multifatorial, necessitando de uma investigação local e sistêmica para identificação dos fatores predisponentes. ${ }^{38}$

\subsubsection{CARACTERISTICAS CLÍNICAS E FATORES PREDISPONENTES}

A estomatite por dentadura pode ser classificada clinicamente em três tipos $^{11,64}$ :

Tipo I: Pontos hiperêmicos em uma área limitada da mucosa. Esse tipo de lesão tem sido relacionado com trauma da prótese.

Tipo II: Eritema difuso na maior parte da mucosa que contacta a prótese. 
Tipo III: Inflamação com hiperplasia papilar. Neste caso, a mucosa apresenta uma aparência nodular com superfície avermelhada, normalmente presente sob toda a área que suporta a prótese, mas pode ainda estar restrita a área central do palato.
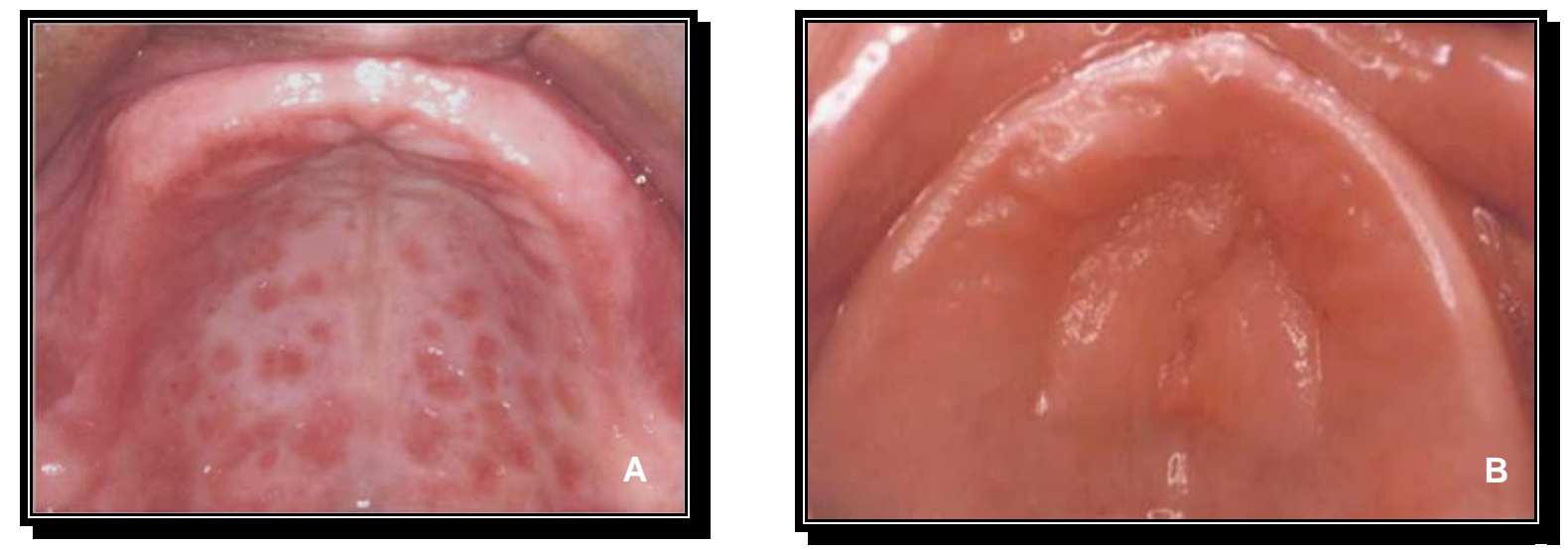

Figura 2: Em A, nota-se candidose crônica atrófica associada ao uso de prótese total superior (tipo I) e, em B, hiperplasia papilar associada ao uso de prótese total superior (tipo III).

(A - caso clínico gentilmente cedido pelo Prof. Dr. Vinicius Carvalho Porto, do Departamento de Prótese, FOB - USP). 
As lesões, se não tratadas, tendem a evoluir do tipo I para o II e em seguida para o III, apesar de existirem algumas dúvidas sobre esse tipo de progressão.

A estomatite por dentadura do tipo III tem sido a mais detectada, o que pode ser conseqüência da manutenção e evolução da estomatite do tipo II. ${ }^{38}$

Os fatores locais têm grande importância na predisposição à estomatite por dentadura, dentre eles o trauma local geralmente pelo uso de próteses totais superiores mal adaptadas, a xerostomia ${ }^{8}$, a alergia a componentes da resina da base da prótese, a higienização inadequada das próteses e ou da cavidade bucal e, ainda, a infecção induzida por Candida. ${ }^{9,43}$

O trauma é considerado por muitos autores como um fator dominante, visto que em pacientes portadores da estomatite por dentadura em fase inicial, ou tipo I, as lesões desaparecem após a remoção da prótese ${ }^{59}$ Entretanto, lesões mais evoluídas, tipos II ou III, necessariamente não regridem com o tratamento protético. $^{11}$

A maioria dos trabalhos demonstra uma forte relação entre higienização deficiente de próteses totais superiores e o aparecimento de estomatite por dentadura $^{32}$, exceto o estudo de Nyquist ${ }^{51}$, em 1953.

A estomatite por dentadura tem sido relacionada com um processo alérgico a material da base da prótese como a resina acrílica. De forma semelhante ao trauma, aspectos clínicos compatíveis com processo alérgico desaparecem com a suspensão do uso da prótese, reaparecendo com a reexposição. Alguns trabalhos relatam ainda reação cutânea positiva ao material da base da prótese em usuários. ${ }^{11,32}$

Há evidências de que a xerostomia, causada por uso contínuo de medicamentos, radioterapia, hábito de fumar tabaco ou a não remoção da prótese durante a noite, está relacionada com a estomatite em pacientes usuários de prótese total superior. Pacientes xerostômicos apresentam um número maior de colônias de Candida, quando examinado a partir da coleta de material através de swab, do que pacientes não xerostômicos. ${ }^{9,32,51,53,59,60}$ O bloqueio da saída do ducto das glândulas salivares pela presença da prótese pode impedir a difusão da saliva no palato, e com isso possibilitar um aumento do processo inflamatório, principalmente nos casos iniciais da estomatite por dentadura. ${ }^{49}$ 
O primeiro relato de infecção por espécies de Candida na estomatite por dentadura foi feito por $\mathrm{Cahn}^{13}$, que isolou maior quantidade de $C$. albicans, através de swab, em pacientes com estomatite por dentadura em comparação a pacientes sem a doença. Espécies de Candida, principalmente a Candida albicans, são encontradas como comensais na cavidade oral de 25 a 50\% dos indivíduos. Nos usuários de prótese total, esses percentuais aumentam para 60 a 100\% dos casos. ${ }^{8,12,34,64}$

Além das alterações locais que podem predispor à estomatite por dentadura, as alterações sistêmicas, como diabetes mellitus e quimioterapia, e o uso de tabaco ou medicamentos, também podem colaborar com a patogênese da estomatite por dentadura, por resultar em um estado de imunossupressão, assim prejudicando os mecanismos de defesa do hospedeiro. ${ }^{62}$ Indivíduos portadores de diabetes mellitus com desordens glicêmicas, que são usuários de próteses totais superiores, têm demonstrado maior quantidade de Candida na mucosa do palato. ${ }^{63}$

A candidose é uma infecção comum entre pacientes portadores de câncer submetidos à quimioterapia, ocorrendo em torno de $50 \%$ dos pacientes leucêmicos em tratamento. ${ }^{43}$

Segundo Oliver et al. ${ }^{53}$ (1984), contradizendo os dados de Bastiaan et al. ${ }^{7}$ (1982), a prevalência da Candida na saliva e no swab oral foi maior nos indivíduos fumantes quando comparados com os não fumantes, sugerindo também que a fumaça do cigarro pode levar a alteração epitelial que facilita a colonização por Candida.

Em especial na presença de fatores sistêmicos associados com os locais, a Candida pode tornar-se patogênica, e assim proliferar nas superfícies da mucosa bem como da prótese total. Para controlar este processo infeccioso, as respostas inflamatórias e imunológicas atuam no sentido de impedir a invasão do fungo, obtendo êxito através de associações de mecanismos que compreendem basicamente a barreira física representada pela superfície epitelial, os componentes salivares e os anticorpos, e células que participam dessa resposta.

\subsubsection{ASPECTOS IMUNOLÓGICOS}

Em análises realizadas em diferentes modelos de infecção por Candida $s p$., incluindo candidose vaginal, oral ou sistêmica, envolvendo tanto indivíduos 
imunocompetentes quanto imunodeprimidos, foi possível verificar o papel protetor da imunidade humoral. Entretanto, não está claro o real envolvimento das células $B$ na resposta a esta infecção fúngica oportunista. ${ }^{4}$

A resistência à infecção por Candida albicans é determinada por mecanismos fagocíticos, atividade que é estimulada por citocinas produzidas por células CD4 ${ }^{+} \mathrm{T}$ helper (Th) 1 , como o interferon (IFN)- $\gamma$ e inibida pelas citocinas do tipo Th2, como a interleucina (IL)-4 e IL-10. Isto se dá pelo fato de que as células Th1 ativam os fagócitos para um estado fungicida enquanto as citocinas Th2 exacerbam a doença por desativarem propriedades protetoras das células fagocíticas contra fungos. ${ }^{63} \mathrm{O}$ receptor de manose, dentre outros, está envolvido diretamente na ingestão de leveduras de Candida albicans pelos macrófagos. Após esta ingestão, o fungo é apresentado para as células $\mathrm{T} \mathrm{CD}^{+}$, que em seguida são ativadas. $^{68}$

Há mudanças marcantes no sistema hematopoiético do idoso e seria inconcebível imaginar que estas alterações não afetassem a resposta imune local, predispondo estes indivíduos a infecções orais com maior freqüência e/ou gravidade, como por exemplo, a estomatite por dentadura. ${ }^{8,54}$

Em relação às subpopulações imunes celulares, as células $T$ apresentam papel essencial na resposta imune de longa duração, desempenhando funções fundamentais para que haja uma resposta imune adaptativa satisfatória. As células T $\mathrm{CD}^{+}$ou Th dirigem o padrão da resposta imune após alguns dias da infecção, direcionando-a para uma resposta celular (Th1) que ativam macrófagos e novos linfócitos T ou para uma resposta basicamente humoral (Th2) com ativação de linfócitos B e alta produção de certos isotipos de anticorpos. Estas células T encontram-se em números diminuídos na corrente sanguínea em humanos idosos, pois estes apresentam capacidade diminuída de proliferação durante a expansão clonal. Além disso, a involução do timo (órgão onde ocorre maturação de linfócitos), que se inicia durante o primeiro ano de vida humana e é nítida já na puberdade, geralmente resulta na perda total deste órgão com o avanço da idade..$^{9,51}$

Com o envelhecimento, são observadas ainda alterações na função imune celular e exacerbação das reações inflamatórias. Estas alterações nos mecanismos de defesa são muito mais marcantes com o avanço da idade do que na presença de fatores genéticos, de ingestão de álcool, dentre outros. . $^{9,41,51}$ 
Uma progressiva redução na massa de tecido hematopoiético é observada com o envelhecimento de seres humanos. Aos 70 anos, a celularidade hematopoiética da medula óssea nas cristas ilíacas é reduzida a $30 \%$ quando comparada àquela encontrada nos jovens adultos. Esta redução pode envolver mudanças intrínsecas de células progenitoras/tronco, e ainda na produção endógena de citocinas, resultando em comprometimento do suporte dependente de contato célula/célula e no aumento da concentração de citocinas supressoras da hematopoiese no sangue periférico, como por exemplo, o fator de necrose tumoral (TNF)- $\alpha$ e a IL-6. ${ }^{68}$

Há uma diminuição marcante no número de células $T$ virgens nos idosos em relação aos jovens ${ }^{9}$, com quase depleção do subgrupo $\mathrm{T} \mathrm{CD8}^{+}$. As alterações numéricas dos linfócitos na terceira idade podem não ser as únicas responsáveis por uma deficiência imune nestes indivíduos. Especula-se que ocorra um desvio no padrão de resposta imune de Th1 (resposta imune celular, protetora principalmente contra fungos e bactérias) para Th2 (resposta humoral, protetora contra parasitas) nestes indivíduos ${ }^{12}$.

\subsubsection{CARACTERÍSTICAS MICROSCÓPICAS E DIAGNÓSTICO}

Em relação às barreiras físicas epiteliais que participam da defesa contra o fungo, alteração na sua espessura e ou no tipo e espessura da camada de queratina podem predispor à invasão fúngica nas células epiteliais mais superficiais. Num estudo de 50 biópsias de pacientes usuários de prótese total superior (1 a 6 anos de uso), foi observada uma diminuição da camada córnea, um epitélio mais delgado com paraqueratose em toda a sua extensão; número de mitoses aumentado e infiltrado inflamatório mononuclear difuso, quando comparados com pacientes usuários de próteses totais superiores novas ou com pacientes não usuários. ${ }^{6,58}$

Na maioria dos casos de estomatite por dentadura, foi observado epitélio paraqueratinizado com cristas alongadas, atrofia epitelial e microabscessos. No tecido conjuntivo fibroso subjacente, foi observado intenso infiltrado inflamatório na região de submucosa, com predomínio de plasmócitos. ${ }^{48,66}$

$\mathrm{Na}$ hiperplasia papilar, a mucosa do palato pode apresentar epitélio ora hiperplásico com cristas alongadas, ora atrófico, sem queratinização ou paraqueratinizado na sua maior extensão, com presença de exocitose, 
microabscessos e acantose. O tecido conjuntivo fibroso subjacente pode demonstrar infiltrado inflamatório de células mono e polimorfonucleares, variando de moderado a intenso, na lâmina própria (subepitelial), e escasso na região de submucosa. ${ }^{10,33}$

Em pesquisa realizada no Brasil, no ano de 2003, em 36 pacientes usuários de prótese total superior, foi observado que o tecido epitelial apresentou áreas de hiperplasia, acantose e espongiose intensa, além de projeções papilares. Também foi observado predomínio de infiltrado inflamatório linfoplasmocitário. ${ }^{38}$

Para o exame microscópico visando o diagnóstico de candidose, pode-se utilizar corantes como a Hematoxilina e Eosina, Prata metanamina de Grocott (PMG) e Ácido periódico de Schiffer (PAS). Observam-se que as leveduras e hifas de Candida albicans e de outras espécies de Candida são fracamente coradas pela Hematoxilina e Eosina, por essa razão os corantes mais comumente utilizados são o PMG e o PAS, entretanto ainda há divergências em relação à detecção de Candida por meio destas colorações. ${ }^{4,5.17,18,23,38,39,47,67}$

O diagnóstico definitivo de estomatite por dentadura, relacionada à infecção fúngica bucal, é dado pela somatória de sinais e sintomas clínicos com exames complementares, como cultura, citológico, histopatológico e sorologia. Entretanto, existe um consenso entre vários pesquisadores que a cultura quantitativa da saliva e a microscopia de esfregaços são suficientes para o estabelecimento do diagnóstico final. ${ }^{38}$

\subsection{CARACTERIZAÇÃO DA MUCOSA NORMAL DO PALATO}

O palato é tradicionalmente dividido em duro e mole. A mucosa do palato duro, disposta de modo a formar a abóbada palatina, mais ou menos arqueada nos diferentes indivíduos, adere-se estreitamente ao osso palatino e, descendo em direção aos dentes, dá lugar a mucosa gengival. Caracteriza-se clinicamente por apresentar superfície lisa e brilhante e sua cor rosa avermelhada. O palato mole prossegue posteriormente apresentando sua superfície lisa ligeiramente brilhante, de cor rosa intenso. ${ }^{1,2,35}$

Microscopicamente, o epitélio bucal constitui uma barreira primária entre o meio bucal e os tecidos mais profundos, sendo escamoso estratificado que consiste de células firmemente unidas umas as outras e arranjadas em camadas ou estratos distintos. O epitélio bucal mantém a sua integridade estrutural pelo processo de 
renovação celular contínuo, no qual as células são produzidas por divisões mitóticas nas camadas mais profundas e migram para a superfície, substituindo as descamadas. Assim, pode-se considerar que as células epiteliais consistem em duas populações funcionais diferentes: uma população progenitora, cuja função é dividir e fornecer novas células, e uma população em maturação cujas células sofrem continuamente um processo de diferenciação ou maturação, para formar uma camada protetora na superfície. . $^{14,15,61}$

O epitélio da mucosa do palato é moderadamente espesso, sendo freqüentemente ortoqueratinizado, embora seja muito normal à existência de áreas paraqueratinizadas. Os dois tipos de superfícies epiteliais são inextensíveis e bem adaptados para suportar a abrasão. A junção entre o epitélio e a lâmina própria subjacente é contorcida, e as numerosas papilas alongadas provavelmente proporcionam uma boa inserção mecânica, capaz de prevenir o desprendimento do epitélio, quando submetido a forças cortantes. A lâmina própria é espessa e contém uma densa rede de fibras colágenas em forma de feixes largos e compridos, as quais seguem um curso direto entre os pontos de ancoragem, tornando-se, assim, um tecido conjuntivo fibroso pouco frouxo, que não cede ao impacto, permitindo que a mucosa resista a cargas pesadas. ${ }^{61}$

Esta mucosa cobre estruturas imóveis e estão firmemente ligadas a ela tanto direta, pela inserção da lâmina própria ao periósteo do osso subjacente, quanto indiretamente, pela submucosa fibrosa. Nas regiões laterais do palato, essa submucosa fibrosa é intercalada por áreas de tecido gorduroso ou glandular que amortecem a mucosa contra as cargas mecânicas, protegendo os vasos sanguíneos e nervos subjacentes na região do palato. ${ }^{61}$

Clinicamente, a mucosa bucal de uma pessoa idosa possui freqüentemente uma superfície mais lisa e mais seca do que nas pessoas mais jovens, e pode ser descrita como atrófica e friável, porem essa descrição, provavelmente, mais decorre das mudanças pelos efeitos cumulativos de doenças sistêmicas, drogas terapêuticas ou ambas, do que de um processo de envelhecimento biológico intrínseco. ${ }^{61}$

Ainda nos idosos, é possível observar que, microscopicamente, o epitélio parece mais fino, e uma interface lisa entre os tecidos epitelial e conjuntivo resulta do achatamento das cristas epiteliais. Na lamina própria, há o decréscimo da celularidade com um aumento na quantidade de fibras colágenas, as quais se 
tornam mais intensamente entremeadas. As células mais numerosas da lâmina própria são os fibroblastos. Entretanto, macrófagos e mastócitos, além de algumas células sanguíneas e do sistema imunológico também estão presentes, bem como células indiferenciadas. ${ }^{35,61}$

Em resumo, considerando a literatura, poucos são os trabalhos abordando os aspectos dos tecidos que suportam as próteses totais. Em virtude da importância de um maior conhecimento destes aspectos, em especial aqueles que podem colaborar para a invasão de microrganismos e dificultar os mecanismos de defesa, objetivamos avaliar as características microscópicas da candidose associada ao uso de prótese total superior, em comparação à mucosa normal da região de palato. Somado a isto, objetivamos ainda traçar um perfil demográfico e clínico dos indivíduos portadores destas lesões e que se submeteram à remoção cirúrgica das mesmas. 
PROPOSIÇÃO 

No presente estudo, o objetivo foi realizar uma análise demográfica, clínica e microscópica da candidose associada ao uso da prótese total superior, nas formas atrófica e hiperplásica papilar, bem como aquela presente na hiperplasia fibrosa inflamatória, em comparação a mucosa normal do palato. 
MATERIAL E MÉTODOS 



\subsection{Obtenção, seleção e caracterização demográfica, clínica e}

\section{microscópica da amostragem}

O material utilizado para este estudo foi selecionado dos arquivos do laboratório de Anatomia Patológica do Departamento de Estomatologia -Área de Patologia- da Faculdade de Odontologia de Bauru, da Universidade de São Paulo, do período de 2000 a 2006. Foi selecionado o maior número possível de lâminas referentes a biópsias humanas de lesões relacionadas ao uso de prótese total superior, e com características microscópicas de candidose. Como controle, foram selecionadas áreas de mucosa com aspectos microscópicos de normalidade, presentes em margens de cortes microscópicos de adenoma pleomórfico de palato (quatro casos), ou amostras de mucosa normal de palato, com suspeita clínica de trauma (um caso) ou lesão cística recidivante (um caso). Todas as amostras deste grupo Controle foram oriundas de pacientes não usuários de prótese total ou removível superior.

Foram obtidas, das fichas clínicas preenchidas pelo cirurgião-dentista que realizou e enviou a biópsia ao referido laboratório de Anatomia Patológica, todas as informações disponíveis para a caracterização demográfica e clínica dos casos selecionados, como:

$\checkmark$ Idade, gênero e raça do paciente ${ }^{31}$,

$\checkmark$ Tempo de evolução da lesão,

$\checkmark$ Presença de lesões múltiplas ou únicas,

$\checkmark$ Sintomatologia,

$\checkmark$ Tempo e freqüência de uso da prótese total superior,

$\checkmark$ Presença de câmara de sucção na prótese total superior,

$\checkmark$ Uso de prótese inferior total ou removível,

$\checkmark$ Descrição clínica da lesão ou das lesões e

$\checkmark$ Diagnóstico clínico.

As lâminas coradas em Hematoxilina e Eosina (H.E.) foram avaliadas através de um microscópio do tipo binocular da marca Olympus $\mathrm{CH}-2$ e classificadas 
em três grupos, considerando também as informações relatadas nas respectivas fichas clínicas:

$\checkmark$ Grupo 1 - estomatite por dentadura atrófica. Foram agrupadas as amostras com diagnóstico microscópico de candidose atrófica ou estomatite por dentadura, e referentes a biópsias de lesões com descrição clínica de região ou pontos avermelhados/eritroplásicos na mucosa do palato de usuários de prótese total superior,

$\checkmark \quad$ Grupo 2 - Hiperplasia fibrosa inflamatória associada à candidose. Foram agrupadas as amostras com diagnóstico microscópico de Hiperplasia fibrosa inflamatória associada à candidose e referentes a biópsias de lesões com descrição clínica de aumento volumétrico ou tumefação na região superior (rebordo, freio labial ou fundo de sulco). O relato de relação com as bordas da prótese total superior foi obrigatório na ficha clínica, para a seleção das amostras deste grupo,

$\checkmark \quad$ Grupo 3 - Hiperplasia papilar. Foram agrupadas as amostras com diagnóstico microscópico de Hiperplasia papilar ou Candidose. A presença de revestimento epitelial com superfície de aspecto microscópico papilar foi obrigatória para a seleção das amostras. As lâminas foram referentes a biópsias de lesões com descrição clínica de aumento volumétrico em palato duro ou, em alguns casos, em rebordo alveolar. Todas as lesões apresentavam associação com prótese total superior, com relato ou não de presença de câmara de sucção.

As lâminas de cada grupo referentes às diferentes amostras foram avaliadas subjetivamente em dois períodos diferentes (com intervalo de três meses). Considerando aquelas referentes ao grupo das hiperplasias papilares, as regiões avaliadas eram preferencialmente aquelas contendo as projeções epiteliais exofíticas papilares e seu tecido conjuntivo subjacente. Da mesma forma, durante a avaliação das lâminas referentes ao grupo das hiperplasias fibrosas inflamatórias associadas à candidose, as regiões selecionadas foram aquelas com o aspecto 
microscópico de candidose, ou seja, epitélio contendo cristas epiteliais alongadas e importante infiltrado inflamatório subepitelial.

Todas as lâminas foram caracterizadas microscopicamente quanto ao:

\section{Revestimento epitelial:}

$\checkmark$ Espessura.

O revestimento epitelial foi considerado hiperplásico quando se apresentou com mais de dez (10) camadas de células, e atrófico quando se apresentou com até quatro (4) camadas ${ }^{61}$.

$\checkmark$ Queratinização.

Foram avaliados os seguintes aspectos: tipo de queratinização (orto ou paraqueratose), sua ausência, bem como sua espessura. A presença de cinco (5) camadas ou mais de queratina foi considerada hiperqueratose ${ }^{61}$.

$\checkmark$ Presença de acantose, de pérolas córneas-like, de cristas alongadas, de cristas em forma de tubo de ensaio e de cristas bífidas.

Ilhotas epiteliais com queratina no seu interior e presentes no tecido conjuntivo fibroso subepitelial foram referidas como pérolas córneas-like, basendo-se no trabalho de Morimoto et al. ${ }^{48}(1987)$.

$\checkmark$ Presença de hiperplasia pseudoepiteliomatosa.

$\checkmark$ Presença de exocitose.

$\checkmark$ Presença de alteração hidrópica.

$\checkmark$ Presença de hipergranulose.

$\checkmark$ Presença de microabscessos de Munro.

$\checkmark$ Presença de reação liquenóide.

Os aspectos: presença de acantose, cristas alongadas, cristas em forma de tubo de ensaio, hiperplasia pseudoepiteliomatosa, exocitose, alteração hidrópica, hipergranulose, microabscessos de Munro e reação liquenóide foram detalhados obedecendo aos seguintes escores: $(+)$ - comprometendo até um terço do 
revestimento epitelial, $(++)$ - comprometendo até dois terços do revestimento epitelial e $(+++)$ - comprometendo a totalidade ou quase todo o revestimento epitelial.

\section{Tecido conjuntivo fibroso subjacente:}

$\checkmark$ Grau do infiltrado inflamatório polimorfonuclear e mononuclear, classificado em discreto, moderado e intenso de acordo com a quantidade presente.

$\checkmark$ Presença de vasos sanguíneos congestos em número aumentado.

$\checkmark$ Localização do infiltrado inflamatório: lâmina própria e ou região perivascular, ou ainda lâmina própria e submucosa.

$\checkmark$ Distribuição do infiltrado inflamatório, quando presente na lâmina própria, sendo detalhado obedecendo aos seguintes escores: $(+)$ comprometendo até um terço da região subepitelial, (++) comprometendo até dois terços da região subepitelial e $(+++)$ comprometendo a totalidade ou quase toda a região subepitelial.

\subsection{Técnicas de coloração especial para detecção de fungo}

Os blocos de parafina, referentes às amostras selecionadas, foram seccionados em micrótomo (Leica RM2165), para a obtenção de cortes consecutivos de $4 \mu \mathrm{m}$, os quais foram colocados sobre lâminas para microscopia e corados por Grocott de prata e Periodic Acid Schiffer (PAS).

Para a realização da coloração por Grocott de prata, as lâminas foram submetidas às seguintes etapas:

$\checkmark$ Desparafinização em três soluções de xilol,

$\checkmark$ Hidratação em álcoois absoluto, 90\% e 70\%,

$\checkmark$ Lavagem em água corrente,

$\checkmark$ Oxidação em ácido crômico a $4 \%$,

$\checkmark$ Lavagem em água corrente,

$\checkmark$ Aplicação de bissulfito de sódio a $1 \%$ durante 1 hora,

$\checkmark$ Lavagem em água corrente, por 10 minutos,

$\checkmark$ Lavagem em água destilada, 3 vezes, 
$\checkmark$ Aplicação de solução de metanamina com nitrato, por 1 hora em estufa a $130^{\circ} \mathrm{C}$,

$\checkmark$ Lavagem em água destilada, 5 vezes,

$\checkmark$ Aplicação de solução com cloreto de ouro a 1\%, por 5 minutos,

$\checkmark$ Lavagem em água destilada,

$\checkmark$ Aplicação de hipossulfito de sódio a $5 \%$, por 5 minutos,

$\checkmark$ Lavagem em água corrente,

$\checkmark$ Aplicação de corante verde luz, por 40 segundos,

$\checkmark$ Desidratação com álcool 95\% e álcool absoluto e

$\checkmark$ Montagem das lâminas.

Para a realização da coloração por PAS, as lâminas foram submetidas às seguintes etapas:

$\checkmark$ Desparafinização em três soluções de xilol,

$\checkmark$ Hidratação em álcoois absoluto, $90 \%$ e $70 \%$,

$\checkmark$ Lavagem em água corrente,

$\checkmark$ Oxidação com ácido periótico a $5 \%$, por 15 minutos,

$\checkmark$ Lavagem em água corrente, por 2 minutos,

$\checkmark$ Aplicação do reativo de Schiffer, por 15 minutos,

$\checkmark$ Aplicação de água sulfurosa, por 2 minutos,

$\checkmark$ Lavagem em água corrente, por 10 minutos,

$\checkmark$ Coloração com hematoxilina de Harris, por 40 segundos,

$\checkmark$ Lavagem em água corrente, por 10 minutos,

$\checkmark$ Desidratação com álcoois $95 \%$ e absoluto e

$\checkmark$ Montagem das lâminas.

Quanto ao estudo microscópico das lâminas submetidas à coloração especial, a proposta foi avaliar a localização e a distribuição de hifas positivas no revestimento epitelial:

$\checkmark$ Localização: apenas na superfície epitelial ou em todas as camadas epiteliais,

$\checkmark$ Distribuição: detalhada obedecendo os seguintes escores: $(+)-$ comprometendo até um terço do revestimento epitelial, $(++)-$ comprometendo até dois terços do revestimento epitelial e $(+++)-$ comprometendo a totalidade ou quase todo o revestimento epitelial. 
RESULTADOS 



\section{RESULTADOS}

\subsection{Caracterização demográfica e clínica da amostragem}

Para este estudo, foram selecionadas, dos arquivos do Serviço de Anatomia Patológica do Departamento de Estomatologia da Faculdade de Odontologia de Bauru - USP, dez (10) amostras de estomatite por dentadura, cinco (5) de hiperplasia fibrosa inflamatória associada à candidose e vinte e duas (22) de hiperplasia papilar provenientes de biópsias de mucosa bucal (região superior) de indivíduos usuários de prótese total superior, residentes em Bauru e região, e seis (6) amostras de mucosa bucal normal.

\subsubsection{MUCOSA NORMAL DE PALATO}

No grupo Controle de mucosa normal de palato, observou-se predominantemente pacientes mulheres ( $3 \mathrm{em} 6)$, considerando que duas amostras (números 4 e 5) foram obtidas da mesma paciente; dois indivíduos negros e outros dois brancos. A idade variou de 33 a 58 anos, com média aproximada de 51 anos.

\subsubsection{ESTOMATITE POR DENTADURA ATRÓFICA (GRUPO 1)}

Com base nas informações registradas pelo clínico que realizou a biópsia, verificaram-se oito pacientes brancos e seis mulheres portadores de estomatite por dentadura atrófica. Duas amostras (números 8 e 9) foram obtidas da mesma paciente, porém uma com localização no lado direito do palato e a outra no lado esquerdo. Quanto à idade dos pacientes, observou-se que esta variou de 36 a 65 anos, com média de aproximadamente 51 anos; entretanto, em dois casos, não houve registro quanto à idade.

Quatro pacientes apresentaram lesões múltiplas, enquanto que em cinco casos (5 em 10 amostras), a lesão era única. Geralmente, não havia relato, nas fichas clínicas, quanto ao tempo de evolução da lesão ou das lesões, exceto dois casos: um deles com relato de lesão de longa data e o outro relatou a lesão há mais 
de um ano. A sintomatologia relacionada à lesão ou às lesões de estomatite por dentadura atrófica também não foi um aspecto geralmente relatado nas fichas clínicas. Somente em um dos casos (1 em 10), houve queixa de ardência e coceira sobre a lesão. Apenas em cinco casos (5 em 10), o clínico sugeriu um diagnóstico para as lesões, as quais foram interpretadas como hiperplasia gengival, candidose, candidíase atrófica, eritroplasia ou reação alérgica ao acrílico. Em todos os casos, a descrição clínica foi de lesões avermelhadas e, em um caso, associada com pontos avermelhados.

Em relação às características da prótese total superior, apenas em um caso houve relato de uso contínuo da prótese, enquanto em outros dois, houve relato do tempo de uso: um deles por longa data e outro há dois anos. Nenhum clínico relatou a presença de câmara de sucção na base da prótese total superior. Apenas um paciente relatou o uso simultâneo de prótese total inferior, enquanto outro de prótese parcial removível inferior.

\subsubsection{HIPERPLASIA FIBROSA INFLAMATÓRIA ASSOCIADA À CANDIDOSE (GRUPO 2)}

No grupo de hiperplasia fibrosa inflamatória associada à candidose, todos os pacientes eram mulheres, brancas. A idade variou de 47 a 75 anos, com média de 60 anos.

Todos os pacientes demonstraram lesão única; em apenas um dos casos, houve relato de sintomatologia dolorosa. Quanto à descrição clínica, três casos (3 em 5) apresentaram-se como lesões hiperplásicas ou tumefatas, não ultrapassando $2 \mathrm{~cm}$ na sua maior dimensão. Em um dos casos, o paciente relatou crescimento rápido para a lesão, há um ano. Em apenas dois casos (2 em 5), houve sugestão para o diagnóstico da lesão, ou seja, hiperplasia fibrosa inflamatória. Em nenhum dos casos, houve a suspeita de presença de candidose associada.

Dois pacientes (2 em 5) com hiperplasia fibrosa inflamatória associada à candidose relataram usar a mesma prótese total superior há oito anos ou mais. Não houve relato quanto à freqüência de uso da prótese total superior. Os clínicos não 
relataram a presença de câmara de sucção nas próteses totais superiores, nem uso simultâneo de prótese inferior.

\subsubsection{HIPERPLASIA PAPILAR (GRUPO 3)}

A idade dos pacientes com hiperplasia papilar variou de 39 a 83 anos, com média de 57 anos; em dez casos, não houve registro quanto à idade dos pacientes. A maioria pertencia ao gênero feminino (18 em 22). De um total de dezessete relatos, doze eram indivíduos brancos, considerando que duas amostras (números 24 e 25) foram obtidas do mesmo paciente.

Poucos relatos ocorreram quanto ao tempo de evolução da lesão (7 em 22); quando presente variou de um mês a 20 anos. A maioria dos pacientes apresentou lesão única (15 em 22). Não havia relato de sintomatologia na maioria dos casos; um paciente relatou sensibilidade à palpação e dois relataram dor, sendo um deles apenas quando provocada. De acordo com as descrições clínicas, geralmente as lesões de hiperplasia papilar apresentaram-se hiperplásicas ou nodulares/tumefatas (13 em 22). Algumas lesões apresentaram-se com cor compatível com a mucosa normal (4 em 22), enquanto outras eram de cor rosa claro (5 em 22), ou avermelhadas (5 em 22) ou, ainda, leucoplásicas (4 em 22). Em alguns casos, os clínicos relataram a presença de irregularidades na superfície da lesão, descrevendo aspecto rugoso, enrugado, moriforme ou papular (6 em 22). As lesões foram consideradas, pelos clínicos, consistentes ou firmes à palpação, em sete pacientes (7 em 22). Quanto ao suposto diagnóstico, oito clínicos acreditaram tratar-se de hiperplasia fibrosa inflamatória (8 em 22), dois de hiperplasia/lesão por trauma da prótese ou hiperplasia por prótese mal adaptada (3 em 22), dois de hiperplasia papilar (2 em 22), um de candidíase (2 em 22) e um de leucoplasia (1 em 22). Associado a suspeita clínica de hiperplasia fibrosa inflamatória, houve o registro de suspeita de fibroma, fibromatose ou papiloma (2 em 22).

Quanto ao tempo de uso da prótese total superior, seis pacientes com hiperplasia papilar mencionaram usar a prótese por cinco anos ou mais, sendo três deles por 20, 35 e 50 anos. Observou-se a presença de câmara de sucção na 
prótese total superior, em cinco pacientes (5 em 22). Um paciente também usava prótese total inferior.

Todos os dados anteriormente descritos estão detalhados nos Quadros 1, 2 e 3. 
Quadro 1 - Caracterização demográfica dos indivíduos submetidos a biópsias de lesões com mucosa normal de palato. As respectivas lâminas foram obtidas dos arquivos da Disciplina de Patologia do Departamento de Estomatologia da Faculdade de Odontologia de Bauru - USP

\begin{tabular}{|c|c|c|c|}
\hline Grupo Controle & Amostra & $\begin{array}{l}\text { Idade do paciente } \\
\text { (anos) }\end{array}$ & Gênero/Raça do paciente \\
\hline \multirow{6}{*}{$\begin{array}{c}\text { MUCOSA NORMAL DE } \\
\text { PALATO } \\
(\mathrm{N}=6)\end{array}$} & 1 & 56 & $\mathrm{M} /-$ \\
\hline & 2 & - & F/Branca \\
\hline & 3 & 51 & M/Negra \\
\hline & 4 & 58 & F/Negra \\
\hline & 5 & 58 & F/Negra \\
\hline & 6 & 33 & F/Branca \\
\hline
\end{tabular}

(-) - não relatado; F - feminino; M - masculino 
Quadro 2 - Caracterização demográfica dos indivíduos portadores e clínica das amostras de lesões de candidose em região superior de boca, obtidas dos arquivos da Disciplina de Patologia do Departamento de Estomatologia da Faculdade de Odontologia de Bauru - USP

\begin{tabular}{|c|c|c|c|c|c|c|c|c|}
\hline \multirow{2}{*}{ Grupos } & \multirow{2}{*}{ Amostra } & \multirow{2}{*}{$\begin{array}{c}\text { Idade do } \\
\text { paciente } \\
\text { (anos) }\end{array}$} & \multirow{2}{*}{$\begin{array}{l}\text { Gênero/Raça } \\
\text { do paciente }\end{array}$} & \multirow{2}{*}{$\begin{array}{c}\text { Tempo de } \\
\text { evolução da lesão }\end{array}$} & \multicolumn{2}{|c|}{$\mathrm{N}^{\circ}$ de lesões } & \multirow{2}{*}{ Sintomatologia } & \multirow{2}{*}{ Diagnóstico clínico } \\
\hline & & & & & Única & Múltiplas & & \\
\hline \multirow{10}{*}{$\begin{array}{l}\text { ESTOMATITE } \\
\text { POR } \\
\text { DENTADURA } \\
\text { ATRÓFICA } \\
\qquad(\mathrm{N}=10)\end{array}$} & 1 & - & M/Branca & - & $x$ & & - & - \\
\hline & 2 & 48 & $\mathrm{~F} /-$ & - & & $x$ & - & - \\
\hline & 3 & 36 & F/Branca & "longa data" & $x$ & & Indolor & Hiperplasia gengival \\
\hline & 4 & 65 & F/Branca & - & $x$ & & - & - \\
\hline & 5 & 51 & F/Branca & - & & $x$ & - & Candidose \\
\hline & 6 & 61 & M/Branca & - & $x$ & & - & Eritroplasia \\
\hline & 7 & - & F/Branca & Há mais de 1 ano & $x$ & & Ardência e coceira & Reação alérgica ao acrílico \\
\hline & 8 & 45 & F/Branca & - & & $x$ & - & - \\
\hline & 9 & 45 & F/Branca & - & & $x$ & - & - \\
\hline & 10 & 61 & M/Branca & - & & $x$ & Assintomático & Candidíase atrófica \\
\hline \multirow{5}{*}{$\begin{array}{c}2 \\
\text { HFI ASSOCIADA } \\
\text { À CANDIDOSE } \\
\qquad(N=5)\end{array}$} & 11 & 55 & F/Branca & - & $x$ & & Assintomático & - \\
\hline & 12 & 47 & F/Branca & 1 ano & $x$ & & - & - \\
\hline & 13 & 59 & F/Branca & - & $x$ & & Dolorosa & - \\
\hline & 14 & 75 & F/Branca & - & $x$ & & - & $\mathrm{HFI}$ \\
\hline & 15 & 67 & F/Branca & - & $x$ & & - & $\mathrm{HFI}$ \\
\hline
\end{tabular}




\begin{tabular}{|c|c|c|c|c|c|c|c|c|}
\hline \multirow{2}{*}{ Grupos } & \multirow{2}{*}{ Amostra } & \multirow{2}{*}{$\begin{array}{l}\text { Idade do } \\
\text { paciente } \\
\text { (anos) }\end{array}$} & \multirow{2}{*}{$\begin{array}{l}\text { Gênero/Raça do } \\
\text { paciente }\end{array}$} & \multirow{2}{*}{$\begin{array}{l}\text { Tempo de } \\
\text { evolução da } \\
\text { lesão }\end{array}$} & \multicolumn{2}{|c|}{$\mathrm{N}^{\circ}$ de lesões } & \multirow{2}{*}{ Sintomatologia } & \multirow{2}{*}{ Diagnóstico clínico } \\
\hline & & & & & Única & Múltiplas & & \\
\hline \multirow{11}{*}{3} & 16 & 44 & F/Branca & - & $x$ & & Assintomático & $\mathrm{HFI}$ \\
\hline & 17 & 49 & F/Branca & - & $\mathrm{x}$ & & Assintomático & $\mathrm{HFI}$ \\
\hline & 18 & 39 & F/Branca & 5 anos & $\mathrm{x}$ & & Assintomático & $\mathrm{HFI}$ \\
\hline & 19 & 73 & F/Branca & 2 anos & $\mathrm{x}$ & & Assintomático & HFI, Fibroma, Fibromatose \\
\hline & 20 & 56 & $\mathrm{~F} /-$ & - & & $\mathrm{x}$ & - & - \\
\hline & 21 & - & M/Branca & - & $x$ & & - & - \\
\hline & 22 & - & F/Branca & 3 anos & & $x$ & Indolor & - \\
\hline & 23 & 43 & F/Negra & - & $x$ & & - & - \\
\hline & 24 & - & M/Branca & - & & $\mathrm{x}$ & - & - \\
\hline & 25 & - & M/Branca & - & & $x$ & - & - \\
\hline & 26 & - & $\mathrm{F} / \mathrm{-}$ & - & $\mathrm{x}$ & & - & - \\
\hline \multirow{11}{*}{$\begin{array}{l}\text { HIPERPLASIA } \\
\text { PAPILAR } \\
\text { (N= 22) }\end{array}$} & 27 & 75 & F/Branca & 1 mês & & $\mathrm{x}$ & Dolorosa & Candidíase e trauma por prótese \\
\hline & 28 & - & F/Negra & - & $x$ & & - & $\begin{array}{l}\text { Mucosa hiperplásica por prótese mal } \\
\text { adaptada }\end{array}$ \\
\hline & 29 & 51 & $\mathrm{~F} / \mathrm{-}$ & - & $\mathrm{x}$ & & Assintomático & HFI \\
\hline & 30 & - & F/- & 20 anos & $\mathrm{x}$ & & Indolor & $\mathrm{HFI}$ \\
\hline & 31 & - & F/Negra & - & $\mathrm{x}$ & & - & Hiperplasia Papilar \\
\hline & 32 & 83 & M/Negra & - & $\mathrm{x}$ & & - & Hiperplasia por trauma de prótese \\
\hline & 33 & - & F/Branca & - & $x$ & & Indolor & - \\
\hline & 34 & 58 & F/Branca & - & & $\mathrm{x}$ & Indolor & HFI, papiloma \\
\hline & 35 & 51 & F/Branca & - & $\mathrm{x}$ & & Sensivel à palpação & $\mathrm{HFI}$ \\
\hline & 36 & 59 & F/Branca & 2 anos & $\mathrm{x}$ & & Dor quando provocada & Leucoplasia \\
\hline & 37 & - & F/- & 2 meses & & $\mathrm{x}$ & Indolor & Hiperplasia papilar do palato \\
\hline
\end{tabular}

(-) - não relatado; HFI - hiperplasia fibrosa inflamatória; F - feminino; M - masculino; $\mathrm{N}^{\circ}$ - número. 
Quadro 3 - Caracterização clínica das amostras de lesões de candidose em região superior de boca, obtidas dos arquivos da Disciplina de Patologia do Departamento de Estomatologia da Faculdade de Odontologia de Bauru - USP

\begin{tabular}{|c|c|c|c|c|c|c|c|}
\hline \multirow[b]{2}{*}{ Grupos } & \multirow[b]{2}{*}{ Amostra } & \multicolumn{3}{|c|}{ Prótese Total superior } & \multicolumn{2}{|c|}{ Usuário de P. Inferior } & \multirow[b]{2}{*}{ Descrição clínica da lesão ou das lesões } \\
\hline & & $\begin{array}{l}\text { Frequência } \\
\text { de uso }\end{array}$ & $\begin{array}{l}\text { Tempo de } \\
\text { uso }\end{array}$ & $\begin{array}{c}\text { Câmara } \\
\text { de } \\
\text { sucção }\end{array}$ & Total & $\begin{array}{c}\text { Parcial } \\
\text { Removível }\end{array}$ & \\
\hline \multirow{7}{*}{$\begin{array}{c}\text { ESTOMATITE } \\
\text { POR } \\
\text { DENTADURA } \\
\text { ATRÓFICA }\end{array}$} & 1 & - & - & - & - & - & Lesão avermelhada no palato \\
\hline & 2 & contínuo & - & - & - & - & $\begin{array}{c}\text { Mucosa hiperplásica com pontos avermelhados em palato e } \\
\text { mucosa alveolar }\end{array}$ \\
\hline & 3 & - & - & - & Sim & & Região hiperêmica em palato duro \\
\hline & 4 & - & - & - & - & - & Lesão eritroplásica de $0,5 \mathrm{~cm}$ em palato duro com secreção \\
\hline & 5 & - & "longa data" & - & - & - & Áreas eritematosas por todo o palato \\
\hline & 6 & - & - & - & - & - & Mancha vermelha em palato duro \\
\hline & 7 & - & 2 anos & - & & Sim & Eritema em palato e rebordo alveolar superior \\
\hline \multirow[t]{3}{*}{$(N=10)$} & 8 & - & - & - & - & - & Lesão vermelha, circular, ciunscrita, em palato duro, lado direito \\
\hline & 9 & - & - & - & - & - & Lesão vermelha, circular, ciunscrita, em palato duro, lado esquerdo \\
\hline & 10 & - & - & - & - & - & Área avermelhada em palato duro \\
\hline \multirow{5}{*}{$\begin{array}{c}\text { HFI } \\
\text { ASSOCIADA À } \\
\text { CANDIDOSE } \\
(\mathrm{N}=5)\end{array}$} & 11 & - & - & - & - & - & Tumefação em rebordo superior, $2 \mathrm{~cm}$, cor normal, séssil \\
\hline & 12 & - & 10 anos & - & - & - & $\begin{array}{c}\text { Lesão em freio labial superior até rebordo alveolar, } 1 \text { cm, } \\
\text { crescimento rápido }\end{array}$ \\
\hline & 13 & - & - & - & - & - & $\begin{array}{l}\text { Tecido mole em fundo de vestíbulo anterior superior, } 20 \text { mm, } \\
\text { consistência mole }\end{array}$ \\
\hline & 14 & - & 8 anos & - & - & - & Hiperplasia na porção anterior do maxilar \\
\hline & 15 & - & - & - & - & - & $\begin{array}{l}\text { Lesão hiperplásica, } 1,5 \mathrm{~cm} \text {, região vestibular de rebordo alveolar } \\
\text { superior }\end{array}$ \\
\hline
\end{tabular}




\begin{tabular}{|c|c|c|c|c|c|c|c|}
\hline \multirow[b]{2}{*}{ Grupos } & \multirow[b]{2}{*}{ Amostra } & \multicolumn{3}{|c|}{ Prótese Total superior } & \multicolumn{2}{|c|}{ Usuário de P. Inferior } & \multirow[b]{2}{*}{ Descrição Clínica da lesão ou das lesões } \\
\hline & & $\begin{array}{l}\text { Freqüência } \\
\text { de uso }\end{array}$ & $\begin{array}{c}\text { Tempo de } \\
\text { uso }\end{array}$ & $\begin{array}{l}\text { Câmara de } \\
\text { sucção }\end{array}$ & Total & $\begin{array}{c}\text { Parcial } \\
\text { Removível }\end{array}$ & \\
\hline \multirow{22}{*}{$(\mathrm{N}=22)$} & 16 & - & & & & & Nódulo no palato duro, cor normal \\
\hline & 17 & - & - & Sim & - & - & Lesão nodular fibrosa em palato duro, $20 \times 20 \times 4$ mm, cor normal \\
\hline & 18 & - & 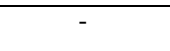 & Sim & - & & Tumefação resiliente em palato duro, $15 \mathrm{~mm}$, cor normal \\
\hline & 19 & - & - & - & - & - & $\begin{array}{l}\text { Nódulo com superficie moriforme, rebordo alveolar superior, crescimento lento, } \\
\text { pediculado, consistente, cor rosa-pálido, } 4 \times 2 \mathrm{~cm}\end{array}$ \\
\hline & 20 & - & 35 anos & - & - & - & Hiperplasias gengivais na região do túber com severa reabsorção óssea \\
\hline & 21 & - & - & - & - & - & Lesão séssil, avermelhada, região central do palato duro \\
\hline & 22 & - & - & - & - & - & Manchas avermelhadas no palato \\
\hline & 23 & - & - & - & - & - & $\begin{array}{l}\text { Lesão hiperplásica em palato duro (rafe mediana), cor rósea, consistência dura, } \\
22 \mathrm{~mm}\end{array}$ \\
\hline & 24 & - & - & - & - & - & Lesões leucoplásicas, rebordo alveolar superior, por vestibular \\
\hline & 25 & - & - & - & - & - & Lesões leucoplásicas, rebordo alveolar superior, por vestibular \\
\hline & 26 & - & - & Sim & Sim & . & Lesão hiperplásica em região central do palato, $0,2 \times 0,2 \mathrm{~mm}$ \\
\hline & 27 & - & 20 anos & - & - & - & Áreas levemente brancas na região central do palato duro \\
\hline & 28 & - & 13 anos & - & - & - & Lesão hiperplásica \\
\hline & 29 & - & 15 anos & Sim & - & - & Lesão de consistência fibrosa, firme à palpação, em palato duro, cor normal \\
\hline & 30 & - & - & Sim & - & - & Placa avermelhada, séssil, firme, superficie rugosa, não sangrante, em palato duro \\
\hline & 31 & - & 50 anos & - & - & - & Lesão vermelha por todo palato \\
\hline & 32 & - & - & - & - & - & Aumento volumétrico na porção mediana do palato, forma irregular, pediculado \\
\hline & 33 & - & - & - & - & - & Lesão de aspecto rugoso na região anterior do palato, 4 mm, avermelhada \\
\hline & 34 & - & - & - & - & - & $\begin{array}{l}\text { Nódulo, cor rósea, fibroso, consistente à palpação, } 2,5 \mathrm{~cm} \text {, em rebordo alveolar } \\
\text { superior (região vestibular), associado a outras lesôes papulares em palato }\end{array}$ \\
\hline & 35 & - & - & - & - & - & $\begin{array}{c}\text { Hiperplasia em rebordo alveolar e palato, } 4 \mathrm{~cm} \text {, séssil, cor rosa-pálido, limites } \\
\text { precisos }\end{array}$ \\
\hline & 36 & - & - & - & - & - & Lesão em rebordo alveolar superior, cor branca, superficie enrugada, $0,5 \mathrm{~cm}$ \\
\hline & 37 & - & 5 anos & - & - & - & Pápulas em palato duro, $2 \mathrm{~mm}$, cor rosa claro, séssil, superficie regular \\
\hline
\end{tabular}

(-) - Não relatado; P. - prótese; HFI - hiperplasia fibrosa inflamatória 


\subsection{Caracterização microscópica da amostragem}

\subsubsection{MUCOSA NORMAL DE PALATO}

As amostras de mucosa bucal normal apresentaram epitélio estratificado pavimentoso com espessura normal e acantose em quase toda a sua extensão. A superfície evidenciou ortoqueratinização (3 em 6) ou paraqueratinização (2 em 6) ou ainda, em apenas uma amostra, hiperortoqueratinização. Vale ressaltar que a paraqueratose estava presente em uma amostra de um paciente fumante (1 maço/dia) e em outra amostra de um paciente com suspeita de lesão cística recidivante, portanto, que já havia sido operado no mesmo local, previamente a esta biópsia. Áreas de ausência de queratina foram notadas em associação com áreas de paraqueratinização (2 em 6) ou de hiperortoqueratinização (1 em 6). Porém, ausência total de queratina, pérolas córneas-like, cristas epiteliais alongadas ou em forma de tubo de ensaio e cristas bífidas não foram observadas.

Em uma amostra, o revestimento epitelial demonstrou reação liquenóide e exocitose, em pequenos focos; tratou-se da amostra oriunda do indivíduo fumante, referido anteriormente. Uma amostra revelou pequenos focos de hipergranulose; esta mesma amostra apresentou epitélio hiperortoqueratinizado (referido no parágrafo anterior). Uma amostra apresentou alteração hidrópica em suas células epiteliais em toda a extensão do revestimento; tratou-se da amostra oriunda do paciente com suspeita de lesão cística recidivante. A presença de microabscesso e hiperplasia pseudoepiteliomatosa não ocorreu nestas amostras.

$\mathrm{Na}$ mucosa normal de palato, notou-se discreto infiltrado inflamatório mononuclear invadindo lâmina própria e região perivascular simultaneamente, em metade das amostras (3 em 6). Vale ressaltar também que duas destas três amostras eram oriundas dos pacientes referidos anteriormente: um fumante e o outro com suspeita de lesão cística recidivante. Em apenas uma amostra (1 em 6), notaram-se vasos sanguíneos congestos; tratou-se da amostra oriunda do paciente fumante. 


\subsubsection{ESTOMATITE POR DENTADURA ATRÓFICA (GRUPO 1)}

Quanto ao tecido epitelial das amostras de estomatite por dentadura atrófica, notou-se revestimento do tipo pavimentoso estratificado. Tal revestimento foi total ou parcialmente hiperplásico em sete casos (7 em 10). Em três casos, a espessura epitelial foi normal em toda a extensão dos cortes examinados (3 em 10). Não se observaram áreas atróficas. Ausência de queratina foi notada em todos os casos: em cinco deles em todo o revestimento epitelial ( 5 em 10), em quatro deles associada com áreas de paraqueratose $(4 \mathrm{em} \mathrm{10}) \mathrm{e}$, em um deles, associada com áreas de ortoqueratose e hiperparaqueratose (1 em 10). Acantose epitelial foi uma característica observada em quase todas as amostras (8 em 10), comprometendo ora até um terço $(3 \mathrm{em} 10)$ ora até dois terços $(1 \mathrm{em} \mathrm{10})$ ora quase todo o revestimento epitelial (4 em 10). De permeio às áreas de acantose, as cristas epiteliais apresentavam-se alongadas. Em metade das amostras, estas cristas foram notadas em quase toda a extensão do revestimento epitelial (5 em 10); enquanto que, em quatro casos, elas comprometiam até um terço (4 em 10) do revestimento epitelial.

Apenas duas amostras de estomatite por dentadura atrófica revelaram cristas epiteliais em forma de tubo de ensaio; as mesmas não ultrapassavam um terço da extensão do revestimento epitelial. Não se observou a presença de cristas epiteliais bífidas. Em três amostras, havia cistos de queratina tipo pérolas córneas subjacente ao revestimento epitelial (3 em 10). Em pequenos focos do epitélio, seis amostras demonstraram reação liquenóide na camada basal (6 em 10) e seis casos revelaram microabscessos de Munro nas camadas epiteliais mais superficiais (6 em 10). Extensas áreas (mais de dois terços da extensão do revestimento epitelial) de hiperplasia pseudoepiteliomatosa foram observadas em cinco das dez amostras, enquanto uma amostra revelou apenas áreas focais desta forma de hiperplasia. A alteração hidrópica nas células epiteliais foi evidente, comprometendo mais de dois terços da extensão do revestimento epitelial, em cinco casos (5 em 10); em quatro casos, esta alteração era focal, não ultrapassando um terço de toda a extensão de tecido epitelial. Todos os casos revelaram exocitose no epitélio por células inflamatórias, sendo que, em cinco casos (5 em 10), comprometendo dois terços ou mais da total extensão epitelial. Não se observou a presença de hipergranulose. 
$\mathrm{Na}$ estomatite por dentadura atrófica, o tecido conjuntivo fibroso apresentou infiltrado inflamatório polimorfonuclear, principalmente discreto (9 em 10). Entretanto, as células mononucleares eram mais numerosas, apresentando-se ora discreta (2 em 10), ora moderada ( 3 em 10) ora intensamente (5 em 10) infiltradas. As células inflamatórias localizavam-se, de forma preferencial, na região perivascular e na lâmina própria (6 em 10), neste último caso ora comprometendo dois terços ou mais da extensão epitelial (4 em 6) ora apenas um terço (2 em 6). Observou-se ainda infiltrado inflamatório exclusivamente em lâmina própria (4 em 10), comprometendo quase toda ou toda a extensão do revestimento epitelial (3 em 4). Apenas três amostras demonstraram células inflamatórias estendendo-se da região de lâmina própria para a submucosa (3 em 10). A presença de vasos sanguíneos congestos não foi observada.

\subsubsection{HIPERPLASIA FIBROSA INFLAMATÓRIA ASSOCIADA À CANDIDOSE (GRUPO 2)}

O revestimento epitelial das hiperplasias fibrosas inflamatórias com candidose associada demonstrou mucosa constituída por epitélio estratificado pavimentoso com espessura normal em quatro amostras (4 em 5), e hiperplásico em duas (2 em 5). Observaram-se epitélio paraqueratinizado em quatro casos (4 em 5), ortoqueratinizado em um (1 em 5) e ausência de queratina em três casos (3 em 5); sendo que: duas amostras apresentaram epitélio paraqueratinizado em toda a sua extensão, apenas uma amostra revelou ausência de queratina em toda a sua extensão, uma amostra demonstrou áreas de paraqueratose associadas com áreas de ausência de queratina, e uma amostra revelou simultaneamente áreas de paraqueratose, ortoqueratose e ausência de queratina. Não se observaram áreas de hiperqueratinização nem cristas epiteliais bífidas. Duas amostras apresentaram cistos de queratina tipo pérolas córneas, na região subepitelial (2 em 5). Em quase todas as amostras, a maior parte da extensão do revestimento epitelial apresentou cristas epiteliais alongadas (4 em 5); em uma amostra, apenas áreas focais de cristas epiteliais alongadas ocorreram. Duas amostras revelaram cristas epiteliais em forma de tubo de ensaio, em pequenos focos, ou seja, não ultrapassando um terço 
do epitélio (2 em 5). Todas as amostras apresentaram acantose, ora até um terço (3 em 5) ora até dois terços (2 em 5) do revestimento epitelial.

Neste grupo, avaliando as camadas basais do epitélio, notou-se reação liquenóide em todas as amostras; normalmente, este aspecto microscópico foi observado em até dois terços do revestimento epitelial (3 em 5). Geralmente, as amostras revelaram a ocorrência de hiperplasia pseudoepiteliomatosa (4 em 5), muitas vezes comprometendo de um a dois terços da extensão do epitélio (3 em 4). O tecido epitelial das amostras demonstrou áreas de alteração hidrópica em suas células (4 em 5), porém em apenas um caso isto ocorria em mais de dois terços do revestimento epitelial (1 em 4). A exocitose foi observada em todas as amostras, e na maior parte delas comprometendo de um a dois terços da extensão epitelial (3 em 5). Os microabscessos de Munro apresentaram-se ora em pequenos focos, não ultrapassando dois terços do revestimento epitelial (2 em 5), ora comprometendo até dois terços deste revestimento (2 em 5). As amostras não revelaram hipergranulose em seu epitélio.

Nas amostras de hiperplasias fibrosas inflamatórias associadas com candidose, as células inflamatórias polimorfonucleares infiltraram o tecido conjuntivo fibroso de forma discreta (5 em 5); entretanto, as células mononucleares ocorriam intensa (3 em 5) ou moderadamente (2 em 5). A lâmina própria apresentou-se invadida, por células inflamatórias, em dois terços ou mais da extensão epitelial, em todas as amostras. Porém, na maioria dos casos, estas células apresentaram-se tanto em região perivascular quanto em lâmina própria (4 em 5). Invasão de células inflamatórias em submucosa não foi observada. Normalmente, as amostras revelaram vasos sanguíneos congestos no tecido conjuntivo fibroso (4 em 5).

\subsubsection{HIPERPLASIA PAPILAR (GRUPO 3)}

O revestimento epitelial do tipo pavimentoso estratificado apresentou-se hiperplásico (11 em 22) ou normal (11 em 22) na hiperplasia papilar; uma amostra revelou tanto áreas hiperplásicas quanto áreas de espessura normal. Áreas de atrofia epitelial foram também observadas em quatro destas amostras (4 em 22). A maior parte das amostras (17 em 22) apresentava revestimento epitelial paraqueratinizado; em quatro delas (4 em 17) havia também áreas de 
hiperparaqueratinização associadas. Na maior parte das amostras, áreas ausentes de queratina foram evidenciadas (18 em 22), sendo que, em quinze delas, tais áreas apresentaram-se associadas com áreas de revestimento epitelial paraqueratinizado (15 em 18). Em poucas amostras, observou-se ortoqueratinização (4 em 22) ou hiperortoqueratinização (1 em 22). Todas as amostras revelaram cristas epiteliais alongadas, na maioria acometendo dois terços ou mais do revestimento epitelial (14 em 22). Havia também áreas focais de cristas epiteliais em forma de tubo de ensaio em doze amostras (12 em 22). Observou-se acantose epitelial de permeio às cristas epiteliais alongadas, ora e mais comumente em pequenos focos (comprometendo até um terço do epitélio) (11 em 22), ora em até dois terços da extensão epitelial (5 em 22), ora comprometendo quase toda a extensão do revestimento epitelial (5 em 22). Metade das amostras avaliadas revelou a presença de pérolas córneas-like (11 em 22) e, em nove amostras, as cristas epiteliais demonstraram aspecto de cristas bífidas (9 em 22).

A reação liquenóide foi uma característica marcante neste grupo (19 em 22), na maioria dos casos não ultrapassando um terço de todo o revestimento epitelial (15 em 19). De forma semelhante, os aspectos microscópicos alteração hidrópica, exocitose e microabscesso de Munro também foram muito evidentes neste grupo, ocorrendo na maioria dos casos (21 em 22; 22 em 22 e 15 em 22, respectivamente), predominando a ocorrência focal, ou seja, que não ultrapassa um terço do revestimento epitelial ( 9 em 21; 11 em 22 e 15 em 15, respectivamente). A maioria das amostras apresentou hiperplasia pseudoepiteliomatosa (18 em 22), geralmente com importante comprometimento, considerando a extensão do revestimento epitelial (até dois terços - 5 em 18, ou quase todo o revestimento epitelial - 8 em 18). A hipergranulose não foi observada na hiperplasia papilar.

O processo inflamatório presente no tecido conjuntivo das amostras de hiperplasia papilar apresentou discretas células polimorfonucleares, na maior parte dos casos (19 em 22). Em três amostras, estas células eram mais numerosas, caracterizando uma infiltração moderada. Como nos outros grupos, as células mononucleares ocorriam mais que as polimorfonucleares, estando presentes de forma moderada (7 em 22) ou intensa (9 em 22) no tecido conjuntivo fibroso. 0 infiltrado de células inflamatórias localizava-se tanto na região perivascular como na lâmina própria (8 em 22), neste último caso, geralmente acometendo quase toda a totalidade do revestimento epitelial (7 em 8). A localização exclusiva das células 
inflamatórias em lâmina própria foi observada em quatorze amostras (14 em 22): em cinco delas, ocorria em até um terço do revestimento, em três em até dois terços e em seis em todo o revestimento de tecido epitelial. $O$ infiltrado inflamatório localizado simultaneamente em lâmina própria e submucosa foi detectado em seis casos (6 em 22). Seis amostras apresentavam vasos sanguíneos congestos no tecido conjuntivo fibroso.

Os dados anteriormente descritos estão detalhados nos Quadros 4 a 8, e demonstrados nas Figuras 3 a 8.

\subsection{Coloração especial}

Por meio da coloração utilizando Grocott de prata e Periodic Acid Schiffer (PAS), não se observou a marcação fúngica em nenhuma das amostras. Apenas houve marcação de células acinares das glândulas salivares e de grânulos queratohialinos. 
Quadro 4: Caracterização microscópica das amostras de mucosa normal de palato, obtidas dos arquivos da Disciplina de Patologia do Departamento de Estomatologia da Faculdade de Odontologia de Bauru - USP

\begin{tabular}{|c|c|c|c|c|c|c|c|c|c|c|c|c|c|c|c|c|c|c|c|c|}
\hline \multirow{3}{*}{ Grupo Controle } & \multirow{3}{*}{ Amostra } & \multicolumn{19}{|c|}{ Revestimento epitelial } \\
\hline & & \multicolumn{3}{|c|}{ Espessura } & \multicolumn{3}{|c|}{ Acantose } & \multicolumn{3}{|c|}{ Cristas alongadas } & \multicolumn{3}{|c|}{$\begin{array}{l}\text { Cristas em forma de } \\
\text { tubo de ensaio }\end{array}$} & \multicolumn{5}{|c|}{ Queratinização } & \multirow{2}{*}{$\begin{array}{l}\text { Pérolas } \\
\text { córneas- } \\
\text { like }\end{array}$} & \multirow{2}{*}{$\begin{array}{l}\text { Cristas } \\
\text { Bífidas }\end{array}$} \\
\hline & & Hiper & Normal & Atrófico & + & ++ & +++ & + & ++ & +++ & + & ++ & +++ & $\mathrm{Pa}$ & & Ort & 0 & Ausente & & \\
\hline \multirow{4}{*}{$\begin{array}{c}\text { MUCOSA } \\
\text { NORMAL DE } \\
\text { PALATO }\end{array}$} & 1 & & $\mathrm{x}$ & & & & $\mathrm{x}$ & & & & & & & $\bar{X}$ & & & & $\mathrm{x}$ & & \\
\hline & 2 & & $\mathrm{X}$ & & & & $\mathrm{x}$ & & & & & & & & & $\mathrm{X}$ & & & & \\
\hline & 3 & & $x$ & & & & $\mathrm{x}$ & & & & & & & & & $X$ & & & & \\
\hline & 4 & & $x$ & & & & $\mathrm{X}$ & & & & & & & & & & $\mathrm{X}$ & $\mathrm{x}$ & & \\
\hline \multirow{2}{*}{$(N=6)$} & 5 & & $\mathrm{x}$ & & & & $\mathrm{X}$ & & & & & & & & & $\mathrm{X}$ & & & & \\
\hline & 6 & & $\mathrm{X}$ & & & & $\mathrm{X}$ & & & & & & & $\mathrm{X}$ & & & & $\mathrm{X}$ & & \\
\hline
\end{tabular}

Hiper - hiperplásico; Para - paraqueratinizado; Orto - ortoqueratinizado; $\mathrm{N}$ - normal; $\mathrm{H}$ - hiper.

\begin{tabular}{|c|c|c|c|c|c|c|c|c|c|c|c|c|c|c|c|c|c|c|c|}
\hline \multirow{3}{*}{ Grupo Controle } & \multirow{3}{*}{ Amostra } & \multicolumn{18}{|c|}{ Revestimento epitelial } \\
\hline & & \multicolumn{3}{|c|}{ Reação Liquenóide } & \multicolumn{3}{|c|}{$\begin{array}{l}\text { Hiperplasia Pseudo- } \\
\text { epiteliomatosa }\end{array}$} & \multicolumn{3}{|c|}{$\begin{array}{l}\text { Alteração } \\
\text { Hidrópica }\end{array}$} & \multicolumn{3}{|c|}{ Exocitose } & \multicolumn{3}{|c|}{ Microabscesso } & \multicolumn{3}{|c|}{ Hipergranulose } \\
\hline & & + & ++ & +++ & + & ++ & +++ & + & ++ & +++ & + & ++ & +++ & + & ++ & +++ & + & ++ & +++ \\
\hline \multirow{5}{*}{$\begin{array}{c}\text { MUCOSA } \\
\text { NORMAL DE } \\
\text { PALATO }\end{array}$} & 1 & $\mathrm{x}$ & & & & & & & & & $X$ & & & & & & & & \\
\hline & 2 & & & & & & & & & & & & & & & & & & \\
\hline & 3 & & & & & & & & & & & & & & & & & & \\
\hline & 4 & & & & & & & & & & & & & & & & $x$ & & \\
\hline & 5 & & & & & & & & & & & & & & & & & & \\
\hline$(N=6)$ & 6 & & & & & & & & & $X$ & & & & & & & & & \\
\hline
\end{tabular}


Quadro 5: Caracterização microscópica das amostras de mucosa normal de palato, obtidas dos arquivos da Disciplina de Patologia do Departamento de Estomatologia da Faculdade de Odontologia de Bauru - USP

\begin{tabular}{|c|c|c|c|c|c|c|c|c|c|c|c|c|c|}
\hline \multirow{4}{*}{ Grupo Controle } & \multirow{4}{*}{ Amostra } & \multicolumn{11}{|c|}{ Infiltrado inflamatório } & \multirow{4}{*}{$\begin{array}{c}\text { Vasos } \\
\text { Sanguíneos } \\
\text { Congestos }\end{array}$} \\
\hline & & \multicolumn{3}{|c|}{ PMN } & \multicolumn{3}{|c|}{ MN } & \multicolumn{5}{|c|}{ Distribuição e localização } & \\
\hline & & \multirow{2}{*}{ D } & \multirow{2}{*}{ M } & \multirow{2}{*}{$\mathbf{I}$} & \multirow{2}{*}{ D } & \multirow{2}{*}{ M } & \multirow{2}{*}{ I } & \multicolumn{3}{|c|}{ Lâmina Própria } & \multirow{2}{*}{ Perivascular } & \multirow{2}{*}{$\begin{array}{c}\text { Lâmina Própria e } \\
\text { Submucosa }\end{array}$} & \\
\hline & & & & & & & & + & ++ & +++ & & & \\
\hline \multirow{4}{*}{$\begin{array}{l}\text { MUCOSA } \\
\text { NORMAL DE } \\
\text { PALATO }\end{array}$} & 1 & & & & $\mathrm{X}$ & & & & & $\mathrm{X}$ & $\mathrm{X}$ & & $\mathrm{X}$ \\
\hline & 2 & & & & & & & & & & & & \\
\hline & 3 & & & & $\mathrm{X}$ & & & & & $x$ & $x$ & & \\
\hline & 4 & & & & & & & & & & & & \\
\hline \multirow{2}{*}{$(N=6)$} & 5 & & & & & & & & & & & & \\
\hline & 6 & & & & $\mathrm{x}$ & & & $\mathrm{X}$ & & & $\mathrm{X}$ & & \\
\hline
\end{tabular}

PMN - polimorfonucleares; MN - mononucleares; D - discreto; M - moderado; I - intenso. 
Quadro 6 - Caracterização microscópica das amostras de lesões de candidose em região superior de boca, obtidas dos arquivos da Disciplina de Patologia do Departamento de Estomatologia da Faculdade de Odontologia de Bauru - USP

\begin{tabular}{|c|c|c|c|c|c|c|c|c|c|c|c|c|c|c|c|c|c|c|c|c|}
\hline \multirow{3}{*}{ Grupos } & \multirow{3}{*}{ Amostra } & \multicolumn{19}{|c|}{ Revestimento epitelial } \\
\hline & & \multicolumn{3}{|c|}{ Espessura } & \multicolumn{3}{|c|}{ Acantose } & \multicolumn{3}{|c|}{ Cristas alongadas } & \multicolumn{3}{|c|}{$\begin{array}{l}\text { Cristas em forma de } \\
\text { tubo de ensaio }\end{array}$} & \multicolumn{5}{|c|}{ Queratinização } & \multirow{2}{*}{$\begin{array}{l}\text { Pérolas } \\
\text { córneas- } \\
\text { like }\end{array}$} & \multirow{2}{*}{$\begin{array}{l}\text { Cristas } \\
\text { Bífidas }\end{array}$} \\
\hline & & Hiper & Normal & Atrófico & + & ++ & +++ & + & ++ & +++ & + & ++ & +++ & \multicolumn{2}{|c|}{ Para } & \multicolumn{2}{|c|}{ Orto } & Ausente & & \\
\hline \multirow{7}{*}{$\begin{array}{c}\text { ESTOMATITE } \\
\text { POR } \\
\text { DENTADURA } \\
\text { ATRÓFICA }\end{array}$} & 1 & & $\mathrm{X}$ & & & & & & & $\mathrm{X}$ & & & & & & & & $\mathrm{X}$ & $\mathrm{X}$ & \\
\hline & 2 & $\mathrm{X}$ & & & $\mathrm{X}$ & & & & & $\mathrm{X}$ & $\mathrm{x}$ & & & $\mathrm{X}$ & & & & $\mathrm{x}$ & & \\
\hline & 3 & $\bar{x}$ & & & $\mathrm{X}$ & & & & & $\mathrm{X}$ & & & & & & & & $\mathrm{X}$ & $\mathrm{X}$ & \\
\hline & 4 & & $\mathrm{X}$ & & & $\mathrm{X}$ & & & $\mathrm{X}$ & & & & & $\mathrm{X}$ & & & & $\mathrm{x}$ & $\mathrm{X}$ & \\
\hline & 5 & $\mathrm{X}$ & & & & & $\mathrm{X}$ & $\mathrm{X}$ & & & & & & & & & & $\mathrm{X}$ & & \\
\hline & 6 & & $\mathrm{X}$ & & & & & & & $\mathrm{X}$ & & & & & & & & $\mathrm{X}$ & & \\
\hline & 7 & $\mathrm{X}$ & & & $\mathrm{X}$ & & & & & $\mathrm{x}$ & $\mathrm{x}$ & & & & & & & $\mathrm{X}$ & & \\
\hline \multirow{3}{*}{$(N=10)$} & 8 & $\mathrm{x}$ & $\mathrm{X}$ & & & & $\mathrm{X}$ & $\mathrm{x}$ & & & & & & $\mathrm{X}$ & & & & $\mathrm{X}$ & & \\
\hline & 9 & $\mathrm{X}$ & $\mathrm{X}$ & & & & $x$ & $\mathrm{x}$ & & & & & & $\mathrm{X}$ & & & & $x$ & & \\
\hline & 10 & $\mathrm{X}$ & $\mathrm{X}$ & & & & $\mathrm{x}$ & $\mathrm{x}$ & & & & & & & $\mathrm{X}$ & $\mathrm{X}$ & & $\mathrm{X}$ & & \\
\hline \multirow{5}{*}{$\begin{array}{c}\text { HFI } \\
\text { ASSOCIADA À } \\
\text { CANDIDOSE }\end{array}$} & 11 & & $\mathrm{X}$ & & & $\mathrm{X}$ & & $\mathrm{X}$ & & & & & & $\mathrm{X}$ & & $\mathrm{X}$ & & $\mathrm{X}$ & $\mathrm{X}$ & \\
\hline & 12 & & $\mathrm{X}$ & & $\mathrm{X}$ & & & & & $\mathrm{X}$ & & & & & & & & $\mathrm{X}$ & & \\
\hline & 13 & $\mathrm{X}$ & $\mathrm{X}$ & & $\mathrm{x}$ & & & & & $\mathrm{X}$ & & & & $\mathrm{X}$ & & & & $\mathrm{X}$ & & \\
\hline & 14 & & $\mathrm{X}$ & & & $\mathrm{x}$ & & & & $X$ & $x$ & & & $X$ & & & & & $X$ & \\
\hline & 15 & $X$ & & & $X$ & & & & & $X$ & $X$ & & & $X$ & & & & & & \\
\hline
\end{tabular}




\begin{tabular}{|c|c|c|c|c|c|c|c|c|c|c|c|c|c|c|c|c|c|c|c|c|c|}
\hline \multirow{4}{*}{ Grupos } & \multirow{3}{*}{ Amostra } & \multicolumn{20}{|c|}{ Revestimento epitelial } \\
\hline & & \multicolumn{3}{|c|}{ Espessura } & \multicolumn{3}{|c|}{ Acantose } & \multicolumn{3}{|c|}{$\begin{array}{l}\text { Cristas } \\
\text { alongadas }\end{array}$} & \multirow{2}{*}{\multicolumn{4}{|c|}{$\begin{array}{c}\text { Crista em forma de } \\
\text { tubo de ensaio }\end{array}$}} & \multicolumn{5}{|c|}{ Queratinização } & \multirow{3}{*}{$\begin{array}{c}\text { Pérolas } \\
\text { córneas- } \\
\text { like }\end{array}$} & \multirow{3}{*}{$\begin{array}{l}\text { Cristas } \\
\text { Bifidas }\end{array}$} \\
\hline & & \multirow[t]{2}{*}{ Hiper } & \multirow[t]{2}{*}{ Normal } & \multirow[t]{2}{*}{ Atrófico } & \multirow[t]{2}{*}{+} & \multirow[t]{2}{*}{++} & \multirow[t]{2}{*}{+++} & \multirow[t]{2}{*}{+} & \multirow{2}{*}{++} & \multirow{2}{*}{ +++ } & \multirow{2}{*}{\multicolumn{2}{|c|}{+}} & \multirow{2}{*}{++} & \multirow{2}{*}{+++} & \multicolumn{2}{|c|}{ Para } & \multicolumn{2}{|c|}{ Orto } & \multirow{2}{*}{ Ausente } & & \\
\hline & & & & & & & & & & & & & & & & $\mathrm{H}$ & & $\mathrm{H}$ & & & \\
\hline & 16 & $x$ & & & $x$ & & & & & & & $\mathrm{x}$ & & & $\mathrm{x}$ & & & & $\mathrm{x}$ & $\mathrm{x}$ & \\
\hline & 17 & $\mathrm{X}$ & & & $\mathrm{x}$ & & & & & & & & & & & & & & $\mathrm{x}$ & $\mathrm{X}$ & \\
\hline & 18 & $\mathrm{X}$ & & & $\mathrm{X}$ & & & & & & & $\mathrm{x}$ & & & 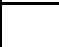 & & & & $\mathrm{X}$ & $\mathrm{X}$ & \\
\hline & 19 & $\mathrm{X}$ & & & & & $\mathrm{x}$ & $\mathrm{x}$ & & & & & & & $\mathrm{X}$ & $\mathrm{X}$ & $\mathrm{x}$ & $x$ & $\mathrm{x}$ & $\mathrm{x}$ & \\
\hline & 20 & & $\mathrm{X}$ & & & & $\mathrm{x}$ & $\mathrm{x}$ & & & & $\mathrm{X}$ & & & $\mathrm{x}$ & $\mathrm{X}$ & $\mathrm{x}$ & & $\mathrm{X}$ & & \\
\hline & 21 & $\mathrm{x}$ & & & & $\mathrm{x}$ & & $\mathrm{x}$ & & & & & & & 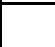 & & & & $\mathrm{X}$ & $\mathrm{X}$ & \\
\hline & 22 & & $\mathrm{X}$ & & & $\mathrm{x}$ & & & & & & $\mathrm{X}$ & & & $\mathrm{X}$ & & & & $\mathrm{x}$ & $\mathrm{X}$ & $\mathrm{x}$ \\
\hline 2 & 23 & & $\mathrm{X}$ & & $\mathrm{X}$ & & & & & & & $\mathrm{X}$ & & & $\mathrm{X}$ & & $\mathrm{x}$ & & & $\mathrm{X}$ & $\mathrm{X}$ \\
\hline 0 & 24 & & $\mathrm{X}$ & & & $x$ & & & $x$ & & & $\mathrm{X}$ & & & $\mathrm{x}$ & $\mathrm{X}$ & & & & & \\
\hline & 25 & & $\mathrm{X}$ & & $\mathrm{X}$ & & & & & & & & & & $\mathrm{X}$ & $\mathrm{X}$ & $\mathrm{X}$ & & & & \\
\hline HIPERPLASIA & 26 & $\mathrm{X}$ & $\mathrm{X}$ & & $\mathrm{X}$ & & & & & & & $\mathrm{X}$ & & & $\mathrm{X}$ & & & & $\mathrm{X}$ & $\mathrm{X}$ & $\mathrm{X}$ \\
\hline PAPILAR & 27 & $\mathrm{X}$ & & & $\mathrm{X}$ & & & & & & & $\mathrm{X}$ & & & $\mathrm{X}$ & & & & $\mathrm{X}$ & & $\mathrm{X}$ \\
\hline & 28 & & $\mathrm{X}$ & & $X$ & & & & & & & & & & $X$ & & & & & & \\
\hline$(\mathrm{N}=22)$ & 29 & & $\mathrm{X}$ & & & $\bar{x}$ & & & $x$ & & & & & & $x$ & & & & $\mathrm{X}$ & & \\
\hline & 30 & $\mathrm{X}$ & & & $x$ & & & & & & & $\mathrm{X}$ & & & $x$ & & & & $x$ & $\mathrm{X}$ & \\
\hline & 31 & $\mathrm{X}$ & & $\mathrm{X}$ & & & $\mathrm{x}$ & $x$ & & & & & & & 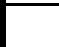 & & & & $\bar{x}$ & & $\bar{x}$ \\
\hline & 32 & & $\mathrm{X}$ & $\mathrm{X}$ & $\mathrm{X}$ & & & & & & & & & & $x$ & & & & $\bar{X}$ & $\bar{X}$ & $\mathrm{X}$ \\
\hline & 33 & & $x$ & & & & $\mathrm{x}$ & $x$ & & & & & & & $x$ & & & & $x$ & & \\
\hline & 34 & & $\mathrm{X}$ & $\mathrm{X}$ & $x$ & & & & & & & $\mathrm{X}$ & & & $x$ & & & & $\mathrm{X}$ & & $\mathrm{X}$ \\
\hline & 35 & $\mathrm{X}$ & & $\mathrm{X}$ & & $\bar{x}$ & & & & & & & $\mathrm{X}$ & & $x$ & & & & $\mathrm{X}$ & $\bar{X}$ & $X$ \\
\hline & 36 & & $\bar{X}$ & & & & & & & & & $\mathrm{X}$ & & & & $X$ & & & $\bar{X}$ & & $\bar{X}$ \\
\hline & 37 & $\bar{X}$ & & & & & $\bar{x}$ & $\bar{x}$ & & & & & & & $x$ & & & & $\mathrm{X}$ & & \\
\hline
\end{tabular}

HFI - hiperplasia fibrosa inflamatória; Hiper - hiperplásico; Para - paraqueratinizado; Orto - ortoqueratinizado; $\mathrm{N}$ - normal; $\mathrm{H}$ - hiper. 
Quadro 7 - Caracterização microscópica das amostras de lesões de candidose em região superior de boca, obtidas dos arquivos da Disciplina de Patologia do Departamento de Estomatologia da Faculdade de Odontologia de Bauru - USP

\begin{tabular}{|c|c|c|c|c|c|c|c|c|c|c|c|c|c|c|c|c|c|c|c|}
\hline \multirow{3}{*}{ Grupos } & \multirow{3}{*}{ Amostra } & \multicolumn{18}{|c|}{ Revestimento epitelial } \\
\hline & & \multicolumn{3}{|c|}{$\begin{array}{c}\text { Reação } \\
\text { Liquenóide }\end{array}$} & \multicolumn{3}{|c|}{$\begin{array}{l}\text { Hiperplasia Pseudo- } \\
\text { epiteliomatosa }\end{array}$} & \multicolumn{3}{|c|}{$\begin{array}{l}\text { Alteração } \\
\text { Hidrópica }\end{array}$} & \multicolumn{3}{|c|}{ Exocitose } & \multicolumn{3}{|c|}{ Microabscesso } & \multicolumn{3}{|c|}{ Hipergranulose } \\
\hline & & + & ++ & +++ & + & ++ & +++ & + & ++ & +++ & + & ++ & +++ & + & ++ & +++ & + & ++ & +++ \\
\hline \multirow{7}{*}{$\begin{array}{c}\text { ESTOMATITE } \\
\text { POR } \\
\text { DENTADURA } \\
\text { ATRÓFICA }\end{array}$} & 1 & & & & & & $x$ & $\mathrm{x}$ & & & $x$ & & & $x$ & & & & & \\
\hline & 2 & $x$ & & & & & & & & & $x$ & & & $x$ & & & & & \\
\hline & 3 & $x$ & & & & & $X$ & & $x$ & & & & $x$ & $x$ & & & & & \\
\hline & 4 & $x$ & & & & & $x$ & & $x$ & & $x$ & & & $x$ & & & & & \\
\hline & 5 & & & & & & $X$ & & & $x$ & & $x$ & & $x$ & & & & & \\
\hline & 6 & & & & $x$ & & & $x$ & & & & & $x$ & & & & & & \\
\hline & 7 & $\mathrm{X}$ & & & & & $x$ & & & $x$ & & & $x$ & & $\mathrm{X}$ & & & & \\
\hline \multirow{3}{*}{$(N=10)$} & 8 & $X$ & & & & & & & $x$ & & $x$ & & & & & & & & \\
\hline & 9 & $x$ & & & & & & $x$ & & & $X$ & & & & & & & & \\
\hline & 10 & & & & & & & $x$ & & & & $x$ & & & & & & & \\
\hline \multirow{5}{*}{$\begin{array}{c}\text { HFI } \\
\text { ASSOCIADA À } \\
\text { CANDIDOSE }\end{array}$} & 11 & & $x$ & & & & $x$ & & $x$ & & $x$ & & & & & & & & \\
\hline & 12 & & $x$ & & $x$ & & & & $x$ & & & $x$ & & $x$ & & & & & \\
\hline & 13 & $x$ & & & & & & & & $x$ & & $x$ & & & $x$ & & & & \\
\hline & 14 & & $x$ & & $x$ & & & $x$ & & & & & $x$ & & $\mathrm{x}$ & & & & \\
\hline & 15 & & & $x$ & & $x$ & & & & & & & $x$ & $x$ & & & & & \\
\hline
\end{tabular}




\begin{tabular}{|c|c|c|c|c|c|c|c|c|c|c|c|c|c|c|c|c|c|c|c|}
\hline \multirow{3}{*}{ Grupos } & \multirow{3}{*}{ Amostra } & \multicolumn{18}{|c|}{ Revestimento epitelial } \\
\hline & & \multicolumn{3}{|c|}{$\begin{array}{l}\text { Reação } \\
\text { Liquenóide }\end{array}$} & \multicolumn{3}{|c|}{$\begin{array}{c}\text { Hiperplasia } \\
\text { Pseudoepiteliomatosa }\end{array}$} & \multicolumn{3}{|c|}{$\begin{array}{l}\text { Alteração } \\
\text { Hidrópica }\end{array}$} & \multicolumn{3}{|c|}{ Exocitose } & \multicolumn{3}{|c|}{ Microabscesso } & \multicolumn{3}{|c|}{ Hipergranulose } \\
\hline & & + & $\begin{array}{lllllll}++ & & l & l & \end{array}$ & 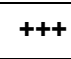 & + & $\begin{array}{lllllll}++ & & l & & & \end{array}$ & +++ & + & ++ & +++ & + & ++ & +++ & + & ++ & +++ & + & ++ & +++ \\
\hline \multirow{10}{*}{3} & 16 & $x$ & & & & $x$ & & $\mathrm{x}$ & & & & $\mathrm{X}$ & & $\mathrm{X}$ & & & & & \\
\hline & 17 & $\mathrm{X}$ & & & & & $\mathrm{x}$ & & & $x$ & & & $\mathrm{x}$ & $x$ & & & & & \\
\hline & 18 & $\mathrm{x}$ & & & & & $x$ & & $\mathrm{x}$ & & & & $x$ & $x$ & & & & & \\
\hline & 19 & $\mathrm{X}$ & & & $\mathrm{x}$ & & & $x$ & & & $x$ & & & $x$ & & & & & \\
\hline & 20 & $\mathrm{X}$ & & & & $\mathrm{x}$ & & $x$ & & & $\mathrm{x}$ & & & $x$ & & & & & \\
\hline & 21 & $\mathrm{X}$ & & & & & $x$ & & & $x$ & $x$ & & & $x$ & & & & & \\
\hline & 22 & $\mathrm{x}$ & & & & & $x$ & & & $x$ & & $x$ & & $x$ & & & & & \\
\hline & 23 & $\mathrm{x}$ & & & & $\mathrm{X}$ & & $\mathrm{x}$ & & & $x$ & & & & & & & & \\
\hline & 24 & $\mathrm{x}$ & & & $\mathrm{x}$ & & & & & & & $\mathrm{x}$ & & & & & & & \\
\hline & 25 & $x$ & & & & & & $x$ & & & $x$ & & & & & & & & \\
\hline \multirow{12}{*}{$\begin{array}{l}\text { HIPERPLASIA } \\
\text { PAPILAR }\end{array}$} & 26 & $\mathrm{x}$ & & & & & $\mathrm{x}$ & & $\mathrm{x}$ & & & & $x$ & $x$ & & & & & \\
\hline & 27 & $\mathrm{x}$ & & & $\bar{x}$ & & & 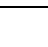 & $x$ & & $x$ & $\mathrm{x}$ & & $\mathrm{x}$ & & & & & \\
\hline & 28 & & & & & & & $x$ & & & $x$ & & & & & & & & \\
\hline & 29 & & & & $x$ & & & & & $x$ & $\mathrm{x}$ & & & & & & & & \\
\hline & 30 & $\mathrm{x}$ & & & & & $\mathrm{X}$ & & & $\mathrm{x}$ & $\mathrm{x}$ & & & $x$ & & & & & \\
\hline & 31 & & $x$ & & $x$ & & & & & $x$ & & & $x$ & & & & & & \\
\hline & 32 & & & $x$ & & $x$ & & & $\mathrm{x}$ & & & & $x$ & $x$ & & & & & \\
\hline & 33 & & & & & & & $x$ & & & $x$ & & & $x$ & & & & & \\
\hline & 34 & & & $x$ & & & & $\mathrm{x}$ & & & & & $\mathrm{x}$ & $x$ & & & & & \\
\hline & 35 & & $x$ & & & & $x$ & $\mathrm{x}$ & & & & $x$ & & $\mathrm{x}$ & & & & & \\
\hline & 36 & $x$ & & & & $\mathrm{x}$ & & & $x$ & & $x$ & & & $x$ & & & & & \\
\hline & 37 & $x$ & & & & & $x$ & & & $X$ & $x$ & & & & & & & & \\
\hline
\end{tabular}


Quadro 8 - Caracterização microscópica das amostras de lesões de candidose em região superior de boca, obtidas dos arquivos da Disciplina de Patologia do Departamento de Estomatologia da Faculdade de Odontologia de Bauru - USP

\begin{tabular}{|c|c|c|c|c|c|c|c|c|c|c|c|c|c|}
\hline \multirow{4}{*}{ Grupos } & \multirow{4}{*}{ Amostra } & \multicolumn{11}{|c|}{ Infiltrado inflamatório } & \multirow{4}{*}{$\begin{array}{c}\text { Vasos } \\
\text { Sanguíneos } \\
\text { Congestos }\end{array}$} \\
\hline & & \multicolumn{3}{|c|}{ PMN } & \multicolumn{3}{|c|}{ MN } & \multicolumn{5}{|c|}{ Distribuição e localização } & \\
\hline & & \multirow{2}{*}{ D } & \multirow{2}{*}{ M } & \multirow{2}{*}{ I } & \multirow{2}{*}{ D } & \multirow{2}{*}{ M } & \multirow{2}{*}{1} & \multicolumn{3}{|c|}{ Lâmina Própria } & \multirow{2}{*}{ Perivascular } & \multirow{2}{*}{$\begin{array}{c}\text { Lâmina Própria e } \\
\text { Submucosa }\end{array}$} & \\
\hline & & & & & & & & + & ++ & +++ & & & \\
\hline \multirow{4}{*}{1} & 1 & $\mathrm{X}$ & & & $\mathrm{X}$ & & & & $\mathrm{x}$ & & $\mathrm{x}$ & & \\
\hline & 2 & $\mathrm{x}$ & & & & $\mathrm{x}$ & & & & $\mathrm{x}$ & & & \\
\hline & 3 & & $\mathrm{X}$ & & & & $\mathrm{x}$ & & & $\mathrm{X}$ & & $\mathrm{X}$ & \\
\hline & 4 & $\mathrm{x}$ & & & & & $\mathrm{x}$ & $\mathrm{X}$ & & & $\mathrm{x}$ & $\mathrm{X}$ & \\
\hline \multirow{6}{*}{$\begin{array}{c}\text { ESTOMATITE } \\
\text { POR } \\
\text { DENTADURA } \\
\text { ATRÓFICA }\end{array}$} & 5 & $\mathrm{X}$ & & & $x$ & & & & & $x$ & & & \\
\hline & 6 & $\mathrm{X}$ & & & & & $\mathrm{x}$ & & & $x$ & $\mathrm{X}$ & & \\
\hline & 7 & $\mathrm{x}$ & & & & $\mathrm{x}$ & & & $\mathrm{X}$ & & $\mathrm{x}$ & & \\
\hline & 8 & $x$ & & & & & $\mathrm{x}$ & & $x$ & & & $\mathrm{X}$ & \\
\hline & 9 & $x$ & & & & & $\mathrm{X}$ & $\mathrm{X}$ & & & $\mathrm{x}$ & & \\
\hline & 10 & $\mathrm{x}$ & & & & $\mathrm{x}$ & & & & $\mathrm{x}$ & $\mathrm{x}$ & & \\
\hline \multirow{5}{*}{$\begin{array}{c}\text { HFI } \\
\text { ASSOCIADA À } \\
\text { CANDIDOSE }\end{array}$} & 11 & $\mathrm{x}$ & & & & $\mathrm{x}$ & & & $\mathrm{x}$ & & & & \\
\hline & 12 & $\mathrm{X}$ & & & & & $\mathrm{X}$ & & & $\mathrm{X}$ & $\mathrm{X}$ & & $\mathrm{x}$ \\
\hline & 13 & $\mathrm{x}$ & & & & $\mathrm{x}$ & & & $\mathrm{x}$ & & $\mathrm{x}$ & & $x$ \\
\hline & 14 & $\mathrm{x}$ & & & & & $x$ & & & $x$ & $\mathrm{x}$ & & $\mathrm{X}$ \\
\hline & 15 & $x$ & & & & & $\mathrm{x}$ & & & $\mathrm{x}$ & $\mathrm{x}$ & & $\mathrm{x}$ \\
\hline
\end{tabular}




\begin{tabular}{|c|c|c|c|c|c|c|c|c|c|c|c|c|c|}
\hline \multirow{4}{*}{ Grupos } & \multirow{4}{*}{ Amostra } & \multicolumn{11}{|c|}{ Infiltrado inflamatório } & \multirow{4}{*}{$\begin{array}{c}\text { Vasos } \\
\text { Sanguíneos } \\
\text { Congestos }\end{array}$} \\
\hline & & \multicolumn{3}{|c|}{ PMN } & \multicolumn{3}{|c|}{ MN } & \multicolumn{5}{|c|}{ Distribuição e localização } & \\
\hline & & \multirow{2}{*}{ D } & \multirow{2}{*}{ M } & \multirow{2}{*}{1} & \multirow{2}{*}{ D } & \multirow{2}{*}{$\mathbf{M}$} & \multirow{2}{*}{$\mathrm{I}$} & \multirow{2}{*}{\multicolumn{3}{|c|}{ Lâmina Própria }} & \multirow{2}{*}{ Perivascular } & \multirow{2}{*}{$\begin{array}{c}\text { Lâmina Própria e } \\
\text { Submucosa }\end{array}$} & \\
\hline & & & & & & & & & & & & & \\
\hline \multirow{22}{*}{$\begin{array}{l}\text { HIPERPLASIA } \\
\text { PAPILAR }\end{array}$} & 16 & $\mathrm{x}$ & & & & $x$ & & & & $\mathrm{x}$ & & & \\
\hline & 17 & $\mathrm{x}$ & & & & & $\mathrm{x}$ & & $\mathrm{x}$ & & & $\mathrm{X}$ & $\mathrm{x}$ \\
\hline & 18 & & $\mathrm{x}$ & & & & $\mathrm{x}$ & & & $\mathrm{x}$ & $x$ & $\mathrm{x}$ & \\
\hline & 19 & $\mathrm{x}$ & & & $\mathrm{x}$ & & & $\mathrm{x}$ & & & & & . \\
\hline & 20 & $x$ & & & $\mathrm{x}$ & & & $\mathrm{x}$ & & & & & $x$ \\
\hline & 21 & $\mathrm{x}$ & & & & $\mathrm{x}$ & & & & $\mathrm{X}$ & $x$ & & \\
\hline & 22 & $\mathrm{x}$ & & & & & $x$ & & & $x$ & $x$ & & \\
\hline & 23 & $\mathrm{x}$ & & & $\mathrm{x}$ & & & $\mathrm{x}$ & & & & & \\
\hline & 24 & $\mathrm{x}$ & & & & $\mathrm{x}$ & & & & $\mathrm{x}$ & $\mathrm{x}$ & & \\
\hline & 25 & $x$ & & & & $\mathrm{x}$ & & & & $\mathrm{x}$ & $\mathrm{x}$ & & \\
\hline & 26 & $\mathrm{x}$ & & & & $\mathrm{X}$ & & & $x$ & & & & \\
\hline & 27 & $\mathrm{x}$ & & & & $\mathrm{x}$ & & & & $x$ & & & \\
\hline & 28 & $\mathrm{x}$ & & & $\mathrm{x}$ & & & $\mathrm{x}$ & & & & & \\
\hline & 29 & $\mathrm{x}$ & & & & & $\mathrm{x}$ & & & $x$ & & & \\
\hline & 30 & $\mathrm{x}$ & & & $\mathrm{x}$ & & & & & $\mathrm{x}$ & $\mathrm{x}$ & & \\
\hline & 31 & & $\mathrm{x}$ & & & & $\mathrm{x}$ & & & $x$ & & $\mathrm{X}$ & \\
\hline & 32 & $\mathrm{x}$ & & & & & $\mathrm{x}$ & & & $x$ & & & $\mathrm{x}$ \\
\hline & 33 & $\mathrm{x}$ & & & & & $\mathrm{x}$ & & $\mathrm{x}$ & & $\mathrm{x}$ & $\mathrm{x}$ & $\mathrm{x}$ \\
\hline & 34 & & $\mathrm{x}$ & & & & $\mathrm{x}$ & & & $\mathrm{X}$ & $\mathrm{x}$ & $\mathrm{x}$ & $\mathrm{x}$ \\
\hline & 35 & $\mathrm{x}$ & & & & $x$ & & & $x$ & & & & \\
\hline & 36 & $X$ & & & $x$ & & & $x$ & & & & & $X$ \\
\hline & 37 & $x$ & & & & & $X$ & & & $X$ & & $X$ & \\
\hline
\end{tabular}

HFI - hiperplasia fibrosa inflamatória; PMN - polimorfonucleares; MN - mononucleares; D - discreto; M - moderado; I - intenso. 

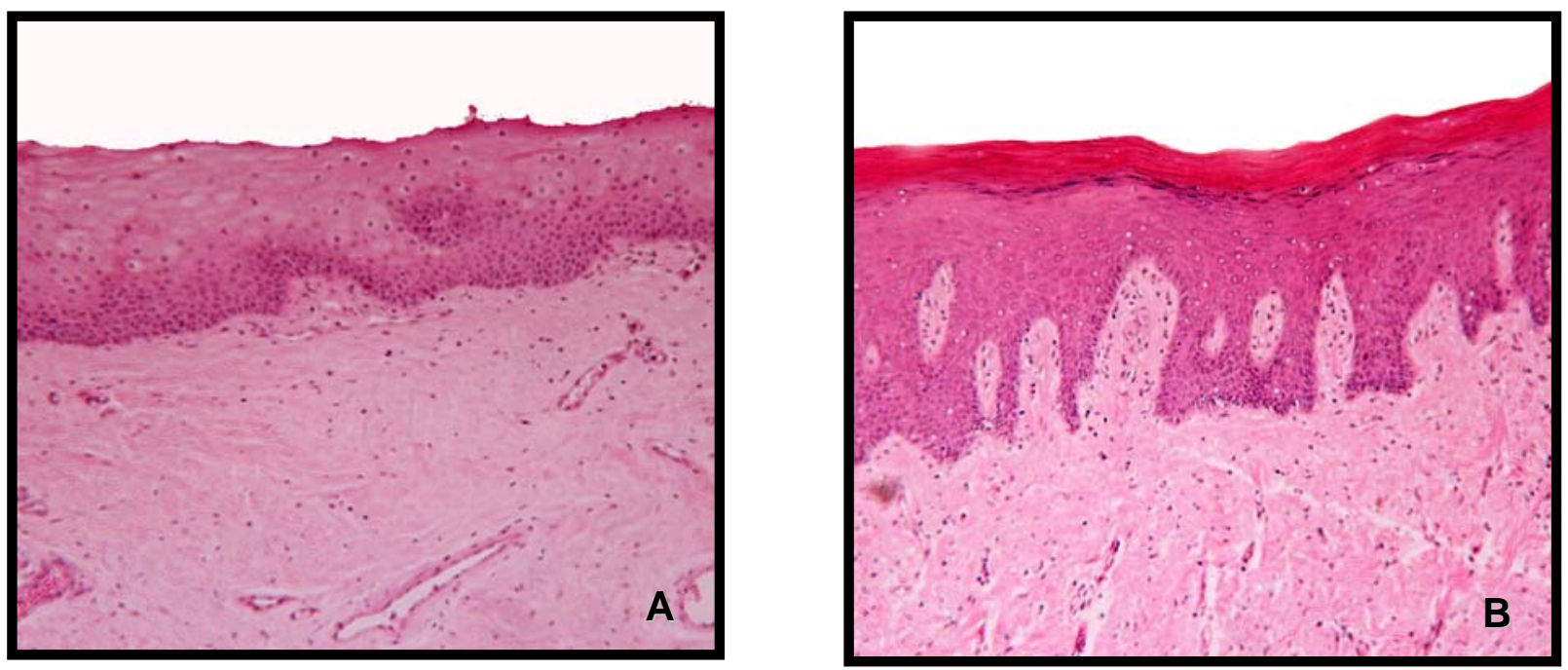

Figura 3 - Mucosa bucal normal. Em A, nota-se área de revestimento epitelial com acantose, ausência de queratina e tecido conjuntivo fibroso subjacente com discreto infiltrado inflamatório mononuclear. Em B, observa-se área de revestimento epitelial com acantose, cristas e ortoqueratose (A e B: H.E.; aumentos originais de $25 x$ ).
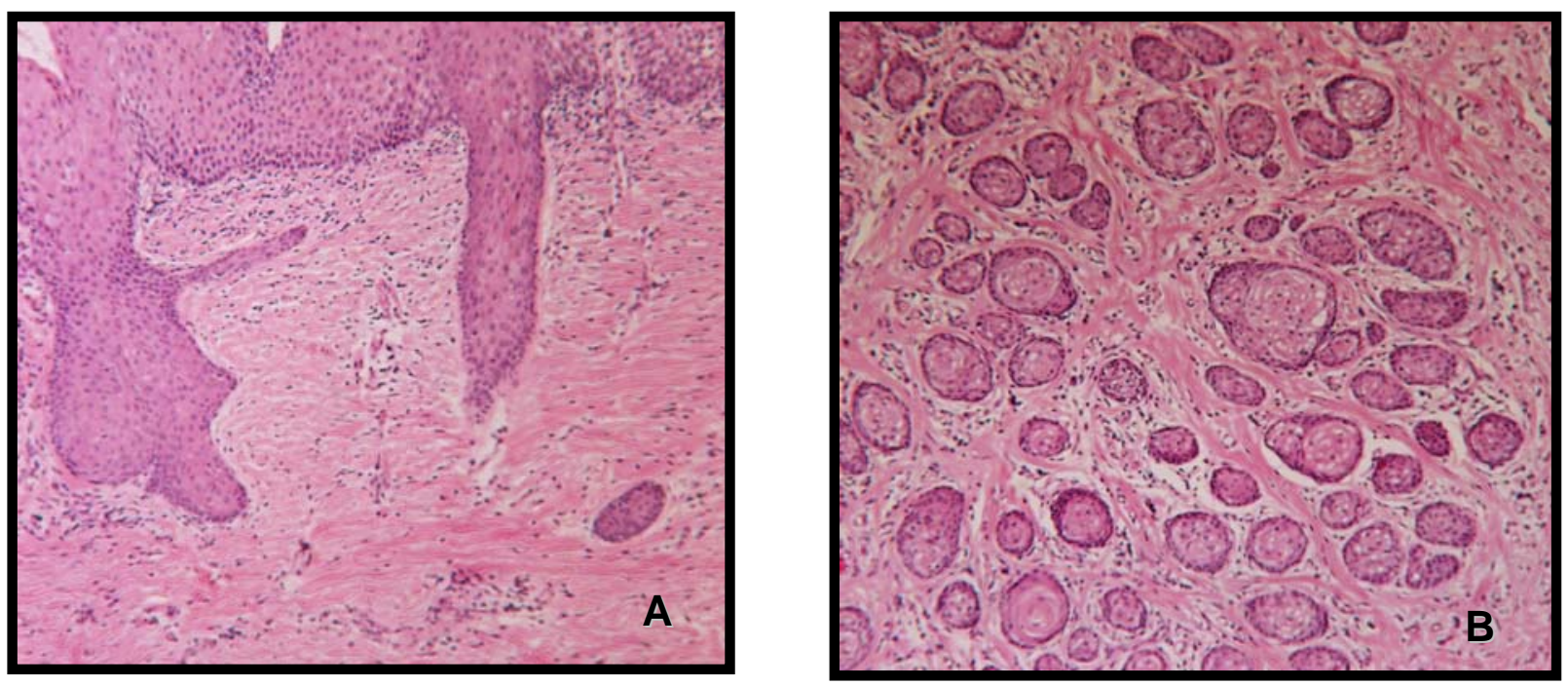

Figura 4 - Estomatite por dentadura atrófica. Cristas epiteliais alongadas e em forma de tubo de ensaio e, no tecido conjuntivo fibroso subjacente, nota-se discreto infiltrado inflamatório mononuclear na região de lâmina própria $(A)$. Em $B$, no tecido conjuntivo fibroso subepitelial, observa-se hiperplasia pseudoepiteliomatosa (A e B: H.E.; aumentos originais de 25x). 

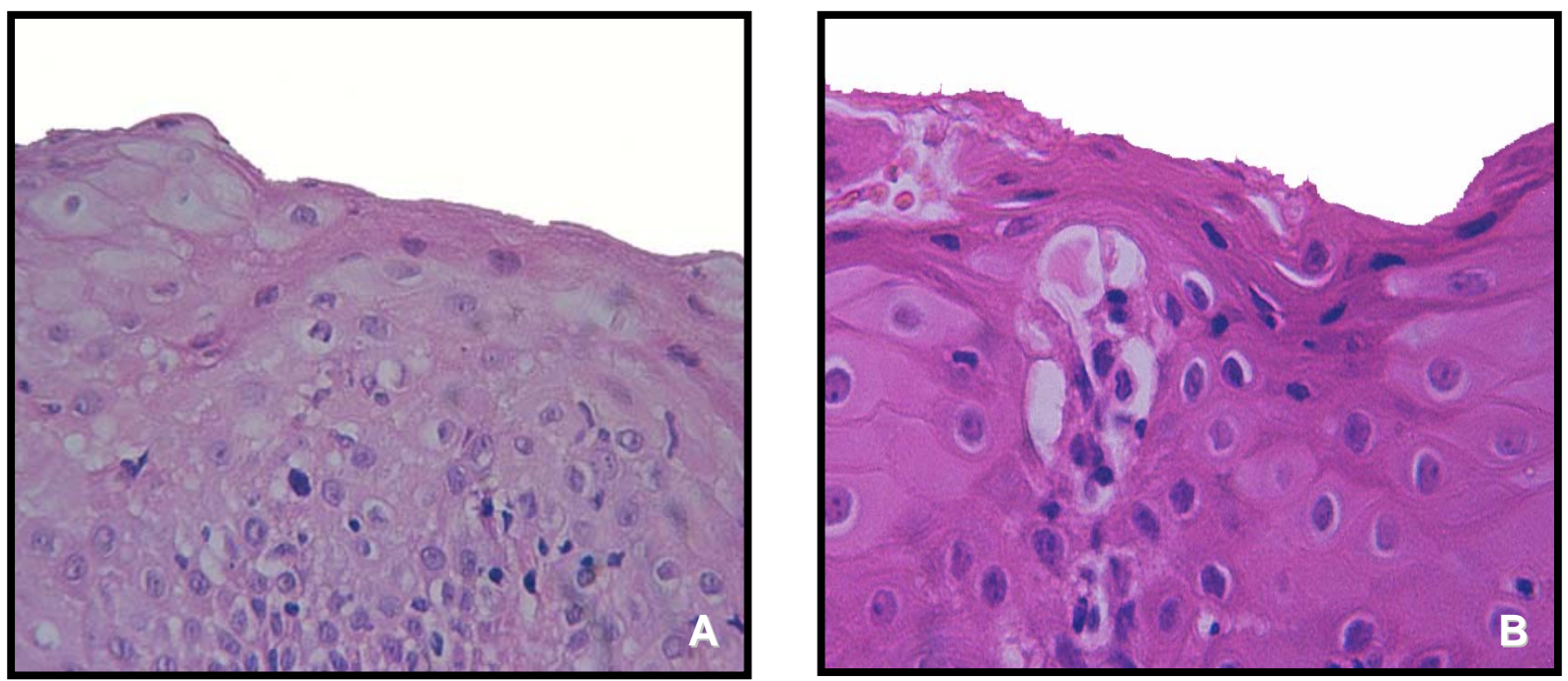

Figura 5 - Estomatite por dentadura atrófica. Em A, nota-se revestimento epitelial com ausência da camada de queratina e, em B, a presença de microabscessos de Munro (A e B: H.E; aumentos originais de $100 x-A$, e $250 x-B$ ).
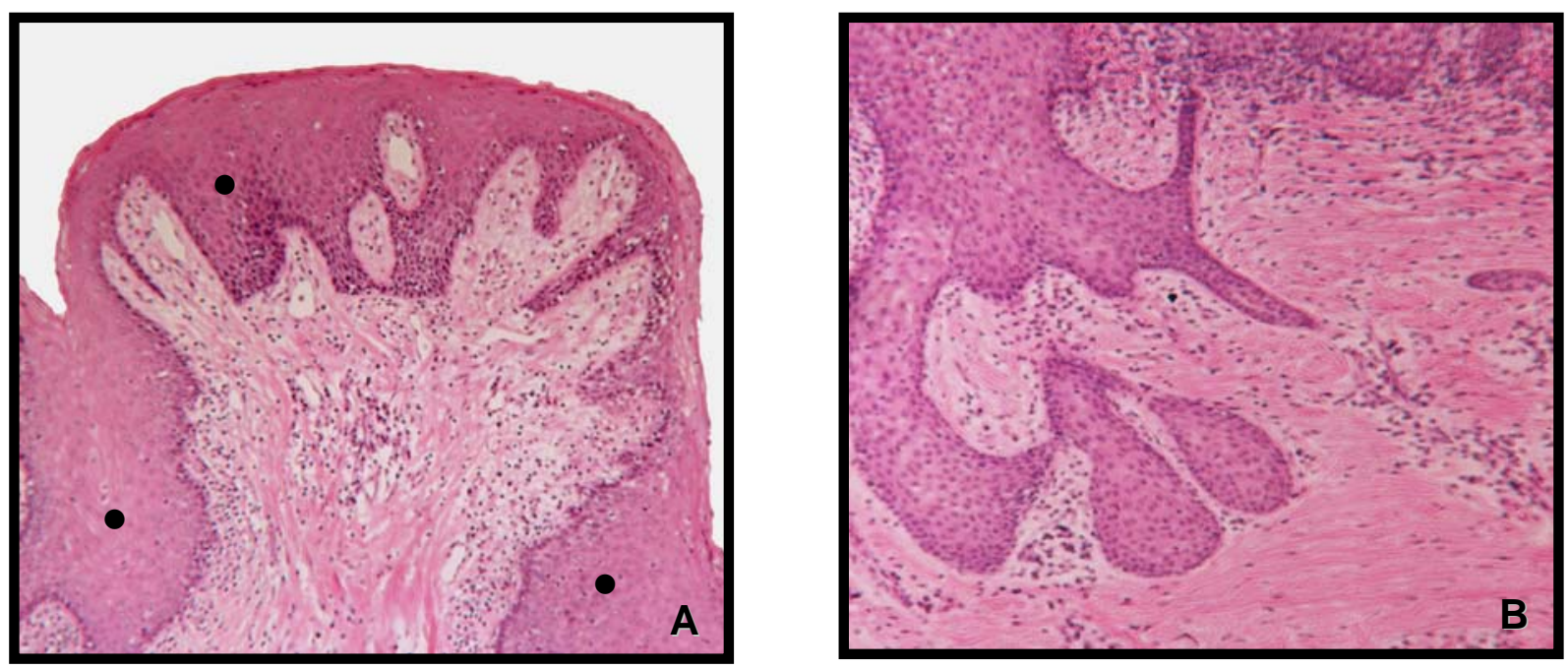

Figura 6 - Hiperplasia papilar. Nota-se revestimento epitelial com áreas de hiperplasia $(\bullet)$ e com projeção papilar (A). Em B, observam-se crista epitelial de aspecto bífido e, no tecido conjuntivo fibroso subjacente, moderado infiltrado inflamatório mononuclear em lâmina própria e região perivascular (A e B: H.E; aumentos originais de 25x). 

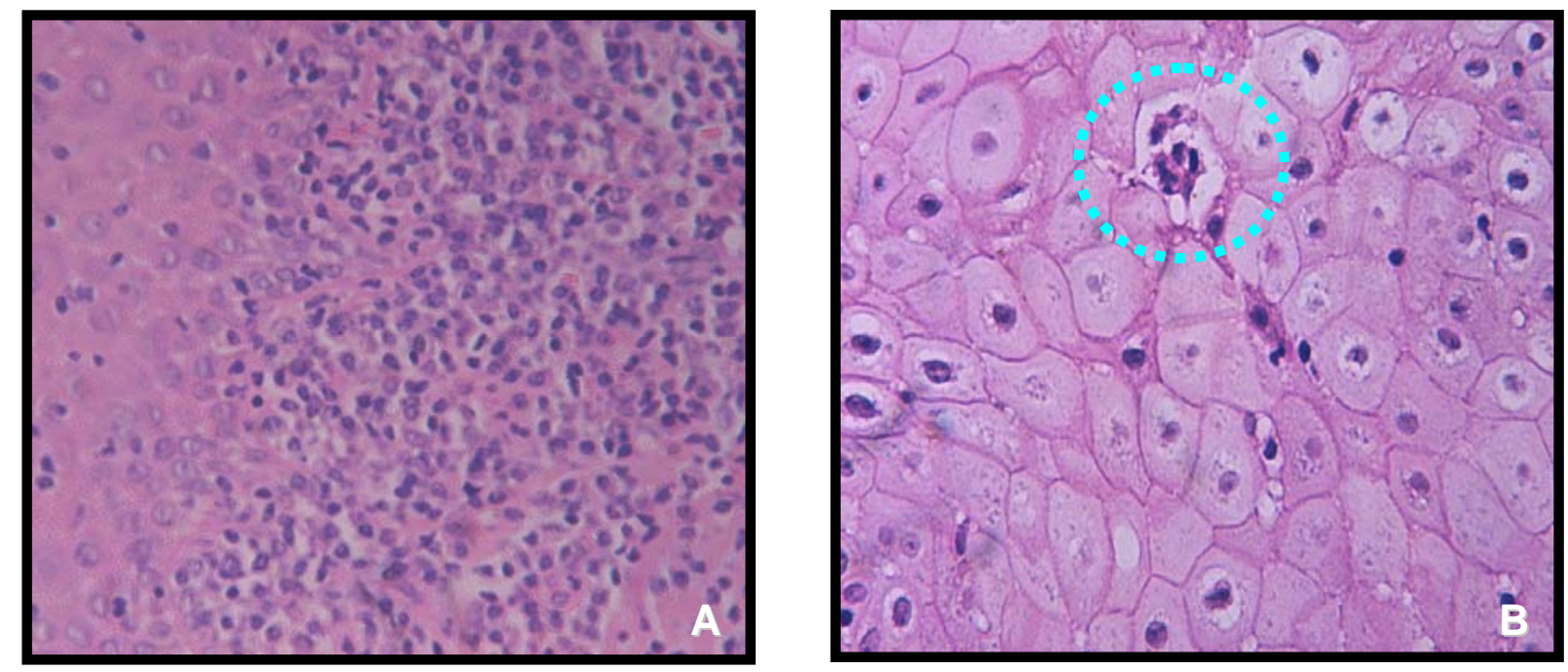

Figura 7 - Hiperplasia papilar. Em A, no tecido epitelial, notam-se reação liquenóide e discreta exocitose, e em B, microabscesso de Munro (círculo azul) (A e B: H.E; aumentos originais de 100x - A, e $250 x-B)$.
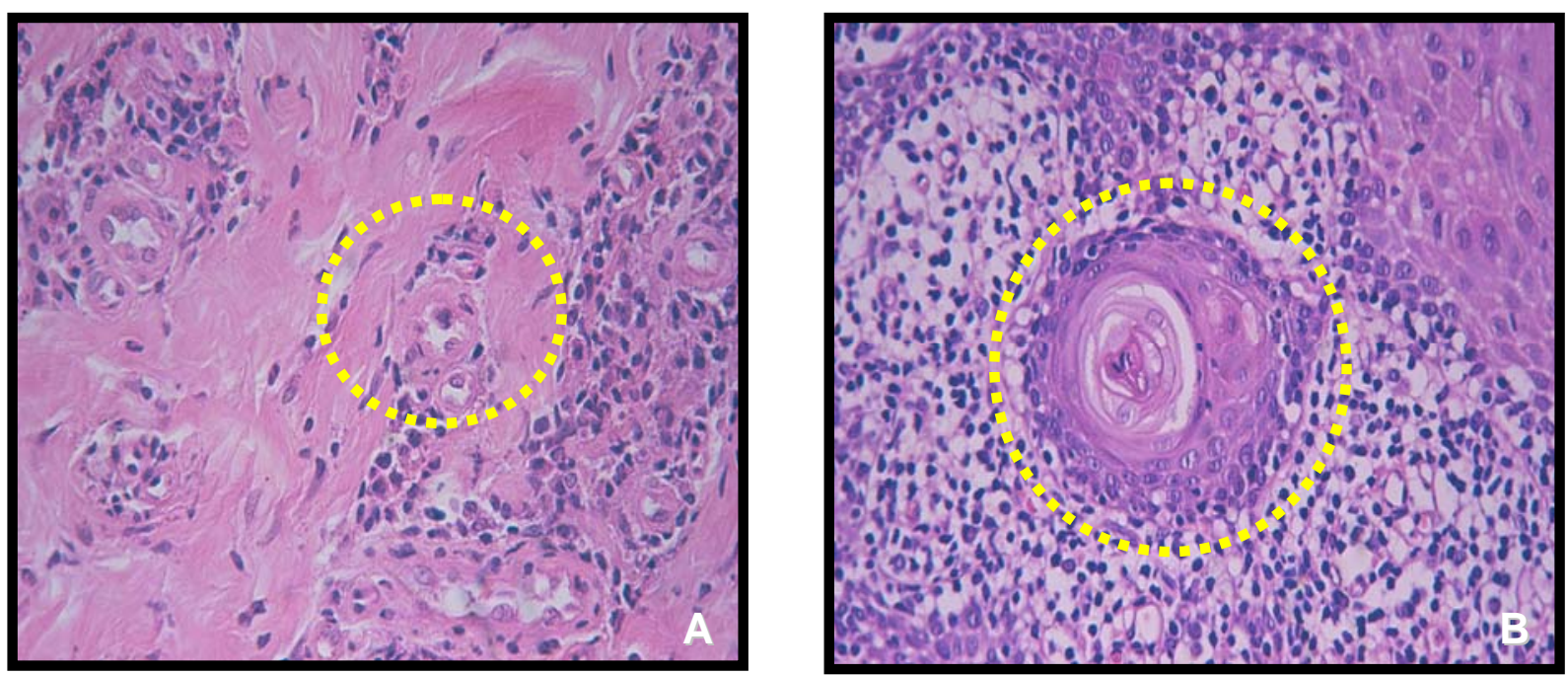

Figura 8 - Hiperplasia papilar. Em A, nota-se tecido conjuntivo fibroso com infiltrado inflamatório mononuclear perivascular (círculo amarelo). Em B, observa-se pérola córnea-like (círculo amarelo) circundada por intenso infiltrado inflamatório mononuclear (A e B: H.E; aumentos originais de 100x). 
DISCUSSÃO 



\section{DISCUSSÃO}

No Brasil, assim como nos países mais desenvolvidos, os progressos tecnológicos e os avanços dos estudos no campo da saúde têm resultado em um aumento na expectativa de vida do homem. O decréscimo das taxas de mortalidade associado à melhoria do saneamento básico também são fatores que resultam numa participação cada vez mais significativa dos idosos na população, significando um processo de envelhecimento populacional rápido e intenso. ${ }^{18,28,40,57}$

A saúde bucal na população idosa ainda tem sido negligenciada; a perda total dos dentes é aceita pela sociedade como uma alteração normal e natural com o avanço da idade, e não como reflexo da falta de políticas preventivas de saúde, destinadas à manutenção dos dentes na boca. Segundo o último levantamento demográfico da população brasileira, existem 11.864 .773 idosos com 60 anos e o último levantamento epidemiológico de saúde bucal da mesma população, ocorrido em 2002-03 e conhecido como SB Brasil 2003 (Condições de saúde bucal da população brasileira), revelou que 3.093 idosos são usuários de prótese total superior, a maioria apresentando estomatite por dentadura. ${ }^{18,28,40,42,45,57}$

Considerando a grande fração de idosos no Brasil e a grande freqüência de estomatite por dentadura nesta população, no presente trabalho, foi realizado um estudo das características demográficas e clínicas dos pacientes usuários de prótese total superior, que apresentaram lesões diagnosticadas como candidose bucal (estomatite por dentadura atrófica - grupo 1; ou hiperplásica - grupo 3; e candidose presente na hiperplasia fibrosa inflamatória - grupo 2). Os grupos foram classificados seguindo Morimoto et al. ${ }^{48}$ (1987) que consideraram as formas atrófica e hiperplásica para a estomatite por dentadura, e Newton ${ }^{49}$ (1962) e BudtzJorgensen \& Bertram ${ }^{11}$ (1970) que dividiram a estomatite por dentadura, de acordo com os sinais clínicos ou microscópicos: I - pequenos pontos avermelhados/inflamação localizada, II - toda a área chapeável avermelhada/inflamação difusa e III - área nodular avermelhada/inflamação granular (hiperplasia papilar), localizada comumente na região central do palato, em contato com a superfície acrílica da prótese.

Primeiramente, observamos que as amostras de candidose bucal, independente do grupo, foram provenientes principalmente de indivíduos idosos, 
com médias variando de 51 a 60 anos, do gênero feminino e raça branca. Estes dados são concordantes com estudos prévios de Morimoto et al. ${ }^{48}$, em 1987, e Wictorin et al. ${ }^{66}$, em 1975, que detectaram a maior prevalência de estomatite por dentadura, incluindo hiperplasia papilar, em idosos. Considerando os indivíduos adultos, é possível que as mulheres procurem mais freqüentemente os serviços de saúde bucal do que os homens, apresentando uma maior preocupação com o tempo de vida de suas próteses e com a saúde de sua mucosa bucal.

De acordo com nosso estudo, as lesões de candidose bucal na região superior normalmente não apresentam sintomatologia dolorosa e podem estar relacionadas com o uso incorreto das próteses, ou seja, por muito tempo. Raramente, os clínicos que realizaram as biópsias apresentam um diagnóstico clínico compatível com o microscópico. Da mesma forma, geralmente os clínicos não relatam informações adicionais quanto à freqüência e tempo de uso das próteses. Estas informações, muitas vezes, têm uma grande importância para o trabalho do patologista na obtenção do diagnóstico final. Não podemos afirmar se isto significa um desconhecimento do clínico em relação à existência das lesões ou à sua etiopatogenia, ou ainda uma valorização deficiente da importância de uma interrelação mais forte entre o clínico e o patologista.

Quando se trata de hiperplasia papilar, as características clínicas de superfície nodular geralmente sugerem fortemente a presença da lesão, permitindo ao clínico, com maior probabilidade, o diagnóstico clínico da lesão. Entretanto, nosso estudo revelou que geralmente o clínico relata a suspeita de hiperplasia fibrosa inflamatória para os casos de hiperplasia papilar. De fato, a hiperplasia papilar representa uma forma de hiperplasia fibrosa inflamatória, em função de sua patogênese ${ }^{15}$, além de representar uma manifestação mais avançada da estomatite por dentadura, muitas vezes decorrente da presença de câmara de sucção ${ }^{49}$, como observado em cinco dos vinte e dois pacientes com hiperplasia papilar do nosso estudo.

Diferente da hiperplasia papilar, a candidose, presente em uma hiperplasia fibrosa inflamatória, provavelmente não será diagnosticada pelo clínico, e sim apenas após observação microscópica. Assim, nestes casos, o clínico sugerirá tratar-se apenas de hiperplasia fibrosa inflamatória, sem a suspeita de presença da doença fúngica associada, como foi observado no presente trabalho. Isto é 
facilmente explicado pelo fato desta associação não apresentar um sinal clínico característico ou sugestivo; os pacientes apresentam apenas as lesões hiperplásicas ou tumefatas correspondentes à hiperplasia fibrosa inflamatória.

A partir de nosso estudo, notamos um maior número de amostras de hiperplasia papilar (22) em comparação às outras. Acreditamos que as hiperplasias papilares são removidas bem mais freqüentemente que a estomatite por dentadura atrófica, cujo diagnóstico geralmente é clínico, não necessitando da remoção cirúrgica para a comprovação diagnóstica, exceto se houver a suspeita de lesão cancerizável, já que a referida estomatite apresenta-se clinicamente como pontos avermelhados ou área eritematosa. As hiperplasias fibrosas inflamatórias associadas com candidose provavelmente são muito raras, considerando que apenas cinco amostras compuseram nosso grupo 2 e que uma das lesões mais freqüentes em nosso arquivo, no laboratório de Anatomia Patológica, são as hiperplasias fibrosas inflamatórias.

No presente trabalho, realizamos, além do estudo clínico e demográfico, uma avaliação das características microscópicas das biópsias dos referidos pacientes. Assim como relatado em estudos prévios, ${ }^{18,17,23,39,44}$ em nosso trabalho não observamos a marcação fúngica por meio das colorações especiais Grocott de prata e PAS, nas amostras de candidose bucal, demonstrando a ineficiência das referidas colorações para fins diagnósticos. Mesmo sem a confirmação do fungo por esta via, metodologias específicas têm demonstrado que a presença do fungo Candida albicans nas camadas epiteliais mais superficiais está amplamente associada com a estomatite por dentadura. ${ }^{8,12,34,64,67}$ Considerando então a presença do fungo na candidose, alterações no tecido epitelial são esperadas, como observadas por Lemos et al. ${ }^{38}$, em 2003, Morimoto et al. ${ }^{48}$, em 1987 e Wictorin et al. ${ }^{66}$, em 1975.

Com o objetivo de melhor caracterizar estas alterações teciduais decorrentes do uso e do contato da mucosa com a prótese total superior e da provável presença da Candida nos tecidos epiteliais, as características microscópicas das amostras de candidose bucal foram comparadas com aquelas da mucosa normal do palato, de indivíduos não usuários de próteses superiores, considerada nosso grupo controle. 
Nosso grupo controle revelou que a mucosa normal do palato apresentase revestida por epitélio estratificado pavimentoso com espessura normal, ou seja, com até 10 camadas de células, acantótico na maior parte de sua extensão e sem cristas epiteliais alongadas, o que está de acordo com os relatos de Ten Cate ${ }^{61} \mathrm{em}$ 2001.

A partir de nossa avaliação, na maior parte dos casos de candidose, ao lado de áreas de espessura normal, o revestimento epitelial apresenta áreas de hiperplasia, em especial na estomatite por dentadura atrófica e hiperplasia papilar. O epitélio, na candidose, mantém o padrão acantótico, mas geralmente em menor extensão e de permeio a cristas alongadas, padrões não observados nos epitélios da mucosa normal. Pequenos focos de cristas epiteliais em forma de tubo de ensaio, como ressaltado por Odell \& Morgan $^{52}$, foram observados na candidose; porém, apenas no grupo das hiperplasias papilares, isto ocorreu em grande parte das amostras.

O fungo Candida albicans causa a produção de citocinas pró-inflamatórias

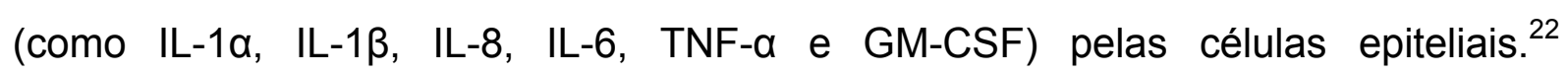
Acreditamos que o fungo ative outras vias intracelulares nas células epiteliais ou mesenquimais, resultando na produção de fatores de crescimento envolvidos com a proliferação e hiperplasia epiteliais. Entretanto, não existem trabalhos na literatura confirmando esta suposição, havendo a necessidade de estudos mais específicos. Devemos considerar ainda a presença do trauma da prótese sobre a mucosa que a suporta, levando a alterações epiteliais que podem refletir um processo de adaptação. $^{56,65}$

Quanto à queratinização, nosso estudo revelou que o epitélio da mucosa, que reveste o palato dos não usuários de prótese, apresenta-se principalmente ortoqueratinizado, podendo demonstrar variações do tipo paraqueratose, hiperortoqueratose e áreas de ausência de queratina, as quais parecem ocorrer em função do fumo ou de um processo de cicatrização. Nas amostras de candidose, geralmente o epitélio permanece paraqueratinizado, mas com áreas de ausência de queratina mais freqüentemente: na maioria dos casos (nos grupos: hiperplasia fibrosa inflamatória associada à candidose e hiperplasia papilar) ou em todas as amostras (grupo: estomatite por dentadura atrófica). Raramente, o revestimento epitelial da candidose apresenta ainda áreas de hiperparaqueratinização com áreas de ortoqueratinização. Acreditamos que a ausência de queratina, observada 
comumente na candidose bucal, ocorre em função do trauma da prótese sobre a mucosa, ou ainda pelo uso contínuo durante todo o dia e toda a noite ou pelo longo tempo de uso da prótese total superior, como ressaltado por Wictorin et al. ${ }^{66}$ (1975). É possível ainda que esta perda de queratinização colabore para a entrada do fungo no tecido epitelial ${ }^{6}$. Em concordância com nossos resultados, Wictorin et al. ${ }^{66}$ (1975), Johannessen et al. ${ }^{33}$ (1986) e Bars et al. ${ }^{6}$ (2001) verificaram alterações morfológicas na camada de queratina.

Nos casos de candidose, o revestimento epitelial da mucosa revelou ainda outras características não compartilhadas pela mucosa normal, como por exemplo, formações císticas epiteliais, geralmente com centro preenchido por queratina, localizadas na região subepitelial, e que lembram os cistos gengivais do adulto. Estes cistos córneos provavelmente representam cristas epiteliais alongadas com centro de queratina e que, em função da técnica para a realização dos cortes histológicos, resultam na falsa impressão de cistos córneos livres ou independentes do revestimento epitelial. Tais cistos, referidos por Morimoto et al. ${ }^{48}$, em 1987, como pérolas córneas-like, ocorreram com maior freqüência, em nosso estudo, no grupo das hiperplasias papilares. Também, neste grupo, observou-se mais freqüentemente a presença de cristas epiteliais bífidas, provavelmente representando intensa proliferação das cristas em direção ao tecido conjuntivo fibroso subjacente. A maior freqüência destas alterações epiteliais nas hiperplasias papilares pode significar um tempo mais prolongado do fungo habitando as células epiteliais, o que dá a oportunidade de uma resposta celular significante com maiores intensidade e freqüência de proliferação das cristas epiteliais. Isto corrobora a afirmação de Newton $^{49}$ (1962) que a forma tipo III de estomatite por dentadura ou hiperplasia papilar pode ser uma evolução das formas mais precoces, referidas como tipos I e II, representando uma resposta mais tardia.

Outros aspectos relacionados com o revestimento epitelial ocorriam na candidose, não sendo ou muito raramente sendo observados na mucosa normal. Em pequenos focos do epitélio nas mucosas com estomatite por dentadura atrófica ou com hiperplasia papilar, observamos reação liquenóide, alteração hidrópica, exocitose e microabscessos de Munro. Nas amostras de hiperplasia fibrosa inflamatória associada à candidose, tais aspectos também ocorriam, porém comprometendo, com mais freqüência, áreas mais extensas do revestimento epitelial, geralmente até dois terços da sua extensão. A reação liquenóide, uma 
alteração celular por liquefação, caracterizada por edema intracelular nas camadas basais do revestimento epitelial, observada em nossas amostras de candidose, representa uma reação imune celular em resposta às células basais, levando a perda das junções epiteliais. ${ }^{3,27,50}$ Possivelmente componentes da resina acrílica da base das próteses, como o formaldeído e o metil metacrilato, ${ }^{62}$ depositam-se nestas células que estão em contato direto. A reação alérgica ao acrílico tem sido reconhecida em muitos trabalhos como um dos mecanismos envolvidos na patogênese da estomatite por dentadura, em especial a hiperplasia papilar, entretanto ainda existem dúvidas sobre a associação desses mecanismos com a presença da Candida albicans..$^{20,21,31,62}$ A exocitose e os microabscessos de Munro, estes últimos encontrados nas camadas mais superficiais do epitélio, também foram observados nos estudos de Wictorin et al. ${ }^{66}$ (1975), Morimoto et al. ${ }^{48}$ (1987), Reeve \& Roekel ${ }^{57}$ (1987), Lemos et al. ${ }^{38}$ (2003) e Coelho et al. ${ }^{19}$ (2004). Estes achados microscópicos são compatíveis com uma resposta de defesa, na qual as células inflamatórias migram para as camadas mais superficiais em busca do fungo, presente na superfície epitelial, na tentativa de eliminá-lo. A liberação local de citocinas com a IL-1a, IL-8 e GM-CSF, pelas células epiteliais em resposta a presença de Candida, pode explicar o achado microscópico de microabscessos nas lesões de candidose, visto que tais citocinas são potentes quimioatraentes e ativadores de polimorfonucleares. ${ }^{22,55}$

A hiperplasia pseudoepiteliomatosa reflete proliferação epitelial reacional ou anormal, em resposta a processos infecciosos, inflamatórios e neoplásicos. ${ }^{12,27}$ Assim como sugerido para a presença de pérolas córneas-like, a hiperplasia pseudoepiteliomatosa representa, em função da técnica para a realização dos cortes histológicos, uma falsa impressão da ocorrência de ilhotas epiteliais livres do revestimento epitelial, simulando invasão epitelial como observada nos carcinomas espinocelulares. Em nosso trabalho, a hiperplasia pseudoepiteliomatosa foi observada geralmente na região subepitelial de quase toda a extensão do revestimento epitelial na amostras dos grupos 1 (estomatite por dentadura atrófica) e 3 (hiperplasia papilar); no grupo 2 (hiperplasia fibrosa inflamatória associada à candidose), esta hiperplasia ocorreu apenas em pequenos focos da região subepitelial.

Em resumo, avaliando nossas amostras de candidose, a estomatite por dentadura atrófica e a hiperplasia papilar são muito semelhantes 
microscopicamente, exceto a maior freqüência de cristas em forma de tubo de ensaio, pérolas córneas-like e cristas bífidas na hiperplasia papilar. Vale ressaltar que a hiperplasia papilar apresenta revestimento epitelial com superfície de aspecto microscópico papilar, ou seja, projeções epiteliais nodulares múltiplas exofíticas, aspectos estes não observados nas outras formas de candidose bucal. Tais projeções podem sugerir alterações semelhantes àquelas observadas nos epitélios de lesões infecciosas como o papiloma e a verruga vulgar, que apresentam projeções papilíferas exofíticas de epitélio pavimentoso estratificado hiperparaqueratinizado. Talvez, o comportamento das células epiteliais frente ao fungo seja semelhante àquele frente a alguns tipos de vírus, como observado no estudo de Chong et al. ${ }^{16}$ (2006), os quais verificaram que as alfa- e beta-defensinas inibem os estádios iniciais de replicação viral, facilitando a resposta epitelial contra os microorganismos.

Quanto ao tecido conjuntivo fibroso subjacente, observamos que a mucosa normal que reveste o palato de indivíduos não usuários de prótese total superior pode apresentar discreto infiltrado inflamatório mononuclear, limitado a lâmina própria e região perivascular, assim como afirmado por Ten Cate ${ }^{61}$ (2001) e Katchburian $^{34}$ (1999), para a mucosa normal de palato. De forma diferente, na candidose bucal, nossas amostras revelaram a presença de discreto infiltrado polimorfonuclear e intenso ou moderado infiltrado mononuclear, corroborando os estudos de Morimoto et al. ${ }^{48}$ (1987), Wictorin et al. ${ }^{66}$ (1975) e Bars et al. ${ }^{6}$ (2001). A localização do infiltrado predominou em lâmina própria e região perivascular nas amostras de estomatite por dentadura atrófica e de hiperplasia fibrosa inflamatória associada à candidose (grupos 1 e 2), e apenas em lâmina própria nas amostras de hiperplasia papilar (grupo 3). A presença de vasos sanguíneos congestos, refletindo intenso fenômeno vásculoexsudativo, foi evidenciada mais freqüentemente nas hiperplasias fibrosas inflamatórias associadas à candidose, provavelmente em função do processo hiperplásico e não da infecção. A presença de infiltrado inflamatório mononuclear na região subepitelial e de vasos sanguíneos congestos também foi observada por Wictorin et al. ${ }^{66}$, em 1975, Johannessen et al. ${ }^{33}$, em 1986 e Morimoto et al. ${ }^{48}$, em 1987.

As células mononucleares têm um importante papel na defesa contra Candida albicans. Os linfócitos colaboram por meio de mecanismos efetores citotóxicos bem como por meio de resposta humoral. Os macrófagos participam da 
resposta de defesa, na candidose, por meio da sua capacidade de apresentação antigênica e regulação da resposta imune. .2,38,48

Considerando todos os resultados de nosso trabalho, as lesões de candidose bucal removidas do palato de usuários de prótese total superior geralmente são indolores, oriundas de mulheres idosas, poucas vezes associadas com o diagnóstico clínico correto e apresentam, como alterações microscópicas mais importantes, hiperplasia epitelial com alongamento das suas cristas, alteração hidrópica, perda de queratinização em áreas de revestimento epitelial paraqueratinizado, exocitose e infiltrado inflamatório mononuclear subepitelial e perivascular, além de alterações pouco realçadas na literatura como a hiperplasia pseudoepiteliomatosa, formações pseudocísticas epiteliais tipo pérolas córneas e cristas bífidas. Apenas em pequenos focos, estas lesões demonstraram, no epitélio, microabscessos e cristas em forma de tubo de ensaio. As alterações microscópicas refletem a presença de um microrganismo no tecido epitelial ou ainda a ação friccional da prótese usada continuadamente ou traumatizando a mucosa. Estes resultados reforçam a necessidade do cuidado com as próteses totais, por parte do usuário, em relação a sua higienização, por meios mecânicos e químicos, bem como em relação ao tempo e freqüência do seu uso. 
CONCLUSÕES

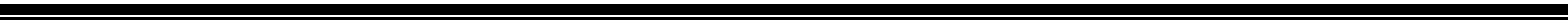





\section{CONCLUSÕES}

Após a análise dos resultados obtidos nesta pesquisa, baseandose nos arquivos do laboratório do Serviço de Anatomia Patológica da FOB USP, concluímos que:

$\checkmark$ As biópsias de candidose bucal foram oriundas predominantemente de pacientes do gênero feminino, raça branca e pertencentes às quinta e sexta décadas de vida.

$\checkmark$ O diagnóstico clínico das lesões de estomatite por dentadura atrófica pode ser difícil, em alguns casos, necessitando de biópsia para confirmação. As lesões de hiperplasia papilar são removidas cirurgicamente com mais freqüência que a estomatite por dentadura atrófica, sendo geralmente reconhecidas pelo profissional clínico como hiperplasia fibrosa inflamatória.

$\checkmark$ Os casos de hiperplasia fibrosa inflamatória associada à candidose são muito raros, considerando a alta casuística de biópsias de hiperplasia fibrosa inflamatória neste Serviço. A candidose nas hiperplasias fibrosas inflamatórias não apresenta sinais clínicos adicionais da sua presença; assim, torna-se improvável a suspeita clínica desta associação.

De forma diferente da mucosa normal, microscopicamente, a maioria dos casos de candidose, em palato de usuários de prótese total superior, apresenta revestimento epitelial hiperplásico com cristas alongadas, algumas em forma de tubo de ensaio, alteração hidrópica, exocitose, freqüentes áreas de ausência de queratina, pequenos focos de reação liquenóide e de microabscessos, bem como extensas áreas de hiperplasia pseudoepiteliomatosa. Subjacente, o tecido conjuntivo fibroso apresenta infiltrado inflamatório mononuclear subepitelial e perivascular. 
$\checkmark$ As características microscópicas na estomatite por dentadura atrófica e hiperplasia papilar são semelhantes, exceto a maior freqüência de cristas em forma de tubo de ensaio, pérolas córneas-like e cristas bífidas na hiperplasia papilar.

$\checkmark$ A coloração especial, por meio de Grocott de prata ou PAS, é ineficiente para a identificação do fungo Candida. Assim, o diagnóstico microscópico da candidose bucal não deve depender da visualização do fungo nas camadas mais superficiais do revestimento epitelial. 
ANEXO 

ANEXO

ANEXO: Aprovação do Comitê de ética em pesquisa da Faculdade de Odontologia de Bauru, Universidade de São Paulo. 
REFERÊNCIAS BIBLIOGRÁFICAS 

1. Allegra F, Gennari PU. Anatomia macroscópica, histologia e ultraestrutura da cavidade bucal. In: . As doenças da mucosa bucal. 1a ed. São Paulo: Editora Santos, 2000. p. 1-18.

2. Allegra F, Gennari PU. As doenças infecciosas da mucosa bucal. In: As doenças da mucosa bucal. 1a ed. São Paulo: Editora Santos, 2000. p. 83-125.

3. Aytikin S, Alp S. Laugier-Hunziker syndrome associated with actinic lichen planus. J Eur Acad Dermatol Venereal, 2004 Mar; 18(2):221-3.

4. Badauy CM, Barbachan JJD, Rados PV, Sant'ana Filho M, Chies JAB. Estudo entre a infecção por Candida $s p$. e a presença de células CD20+ em hiperplasias inflamatórias. Rev Fac Odontol Porto Alegre, 2004;45(1):44-47.

5. Badauy CM, Barbachan JJD, Rados PV, Sant'ana Filho M, Chies JAB. Relationship between Candida infection and immune cellular response in inflammatory hyperplasia. Oral Microbiol Immunol, 2005;20:89-92.

6. Bars PL, Piloquet P, Daniel A, Giumelli B. Immunohistochemical localization of tipe IV collagen and laminin $(\alpha 1)$ in denture stomatitis. Int J Oral Surg, 2001;30:98-103.

7. Bastiaan RJ, Reade PC. The prevalence of Candida albicans in the mouths of tobacco smokers with and without oral mucous membranes keratoses. Oral Surg Oral Med Oral Pathol, 1982 Feb;53(2):148-51.

8. Berdicevsky I, Ben-Aryeh H, Szargel R, Gutman D. Oral Candida of asymptomatic denture wearers. Int J Oral Surg, 1980 Apr;9(2):113-15. 
9. Budtz-Jorgensen E. Clinical aspects of Candida infection in denture wearers. JADA, 1978 Mar;96(3):474-79.

10. Budtz-Jorgensen E. Histopathology, immunology, and serology of oral yeast infections: diagnosis of oral candidosis. Acta Odont Scand, 1990 Feb;48(1):37-43.

11. Budtz-Jorgensen E, Bertram T. Denture stomatitis 1: The etiology in relation to trauma end infection. Acta Odont Scand, 1970 Jun;28(2):71-92.

12. Budtz-Jorgensen E, Stenderup A, Grabowski M. An epidemiologic study of yeasts in elderly denture wearers. Commu Dent Oral Epidem, 1975 May;3(3):115-19.

13. Cahn LR. The denture sore mouth. Ann Dent, 1936;3(1):33-6.

14. Cawson RA, Binnie WH, Eveson JW. Estomatites. In:

Atlas colorido de enfermidades da boca: correlações clínicas e patológicas. 2a ed. São Paulo: Artes médicas; 1997. p. 11.2-11.33.

15. Cawson RA, Binnie WH, Eveson JW. Tumores do epitélio bucal. In: Atlas colorido de enfermidades da boca: correlações clínicas e patológicas. 2a ed. São Paulo: Artes médicas; 1997. p. 13.2-13.17.

16. Chong K, Xiang L, Wang X, Jun EL, Xi L, Schweinfurth. High level expression of human epithelial $\beta$-defensina (hBD-1, 2 and 3 ) in papillomavirus induced lesions. Virol J, 2006 sep;8(3):75-83.

17. Clayden EC. Practical section cutting and staining. In: Paraffin wax sections. 4 ed London, 1962. p84-85.

18. Clayden EC. Practical section cutting and staining. In: Paraffin wax sections. 4 ed London, 1962. p106-107. 
19. Coelho CMP, Sousa YTCS, Daré AMZ. Denture-related oral mucosal lesions in a Brasilian school of dentistry. J Oral Rehabil, 2004;31:135-39.

20. Danilewicz-Stysiak Z. Allergy as a cause of denture sore mouth. J Prost Dent, 1971;25(1):16-18.

21. Devlin H, Watts DC. Acrylic "Allergy"?. Br Dent J, 1984 Oct;157(8):272-75.

22. Dongari-Bagtzoglou A, Fidel Jr PL. The host cytokine responses and protective immunity in oropharyngeal candidiasis. J Dent Res, 2005 april;84(11):966-77.

23. Eda S, Fukuyama H, Kitamura K, Nagai N, Utsumi N, Yamamura $\mathrm{T}$, et al. Inflammation. In: A laboratory manual for general and oral pathology. 1a ed. São Paulo: Quintessence; 1990. p. 41-56

24. Espinoza I, Rojas R, Aranda W, Gamonal J. Prevalence of oral mucosal lesions in elderly people in Santiago, Chile. J Oral Pathol Med, 2003;32:571-5.

25. Farah CS, Ashman RB, Challacombe SJ. Oral candidosis. Clin Dermatol, 2000;18:553-62.

26. Fotos PG, Hellstein JW, Vincent SD. Oral candidosis revisited. Gen Dent, 1991 Nov-Dec;39(6):422-30.

27. Fu X, Jiang D, Chen W, Sun T, Sheng Z. Pseudoepitheliomatous hyperplasia formation after skin injury. Wound Rep Reg, 2007;15:39-46.

28. Gaião LR, Almeida MEL, Heukelbach J. Perfil epidemiológico da cárie dentária, doença periodontal, uso e necessidade de prótese em idosos residentes em uma instituição na cidade de Fortaleza, Ceará. Rev Bras Epidemiol, 2005; 8(3):316-23. 
29. Gompertz OF, Gambale W, Paula CR, Corrêa B. Micoses oportunísticas e outras micoses. In: Trabulsi LR, Alterthum F. Microbiologia. 4a ed São Paulo: Atheneu; 2005. p. 495-97.

30. Hofling JF, Barros LM, Alves ACBA, Mariano PLS, Gonçalves RB. Colonização bucal por espécies de Candida: prevalência e colonização. Rev Fac Odontol Passo Fundo, 2004;9(1):16-21.

31. IBGE - Instituto Brasileiro de Geografia e Estatística. [homepage na Internet]. Brasília, DF: IBGE; [acesso em 2007 Fevereiro 20]. Disponível em: http://www.ibge.com.br.

32. Jeganathan S, Lin CC. Denture stomatitis: a review of the aetiology, diagnosis and management. Aust Dent J, 1992 Apr;37(2):107-14.

33. Johannessen AC, Isacsson G, Nilsen R, Bergendal T. In situ characterization of the inflammatory cell infiltrates of hyperplastic denture stomatitis. Acta Odont Scand, 1986 Jun;44(3):185-92.

34. Jorge AE, Broglio LZ, de Almeida OP, Jorge Junior J. Estomatite por prótese total - presença de bactérias e fungos. Arq Cent Estud Curso Odontol, 1990 Jan-Dec;27(1-2):9-15.

35. Katchburian E, Arana V. Mucosa oral. In: 1a ed. Rio de Janeiro: Guanabara Koogan; 1999. p. 77-117.

36. Kulak-Ozkan Y, Kazazoglu E \& Arikan A. Oral hygiene habits, denture cleanliness, presence of yeasts and stomatitis in elderly people. J Oral Rehabil, 2002 Mar;29(3):300-04.

37. Kupp LI, Sheridan PJ. Denture sore mouth. Dermatol Clin, 2003;115-22. 
38. Lemos MMC, Miranda JL, Souza MSGS. Estudo clínico, microbiológico e histopatológico da estomatite por dentadura. Rev Bras Patol oral, 2003 jan/mar;2(1):3-10.

39. Lillie RD. Bacteteria, protozoa and other parasites. In:

Histopathologic technic and practical histochemistry. 1a ed. New York: Blakisnton, 1954. p. 57-62

40. Lockhart SR, Joly K, Vargas K, Swails-Wenger J, Enger L, Soll DR. Naural defenses against Candida: colonization breakdown in the oral cavities of the elderly. J Dent Res, 1999 April;78(4):857-68.

41. Loning TH, Broemel H, Beker WM, Otto HF. Identification of inflammatory cell phenotyptes in human oral carcinomas by means of monoclonal antibodies. Arch Oral Biol, 1983;28:1093-100.

42. Marsh $P$, Martin MV. Infecções orais fúngicas. In: Microbiologia oral. 4a.ed. São Paulo: editora Santos; 2005. p153-62.

43. McElroy TH. Infection in the patient receiving chemotherapy for cancer: oral considerations. J Am Dent Assoc, 1984 Sep;109(3):454-6.

44. Ministério da Saúde. O problema do câncer no Brasil. In: Ações de enfermagem para o controle do câncer: uma proposta de integração e ensino. 2a ed. Rio de Janeiro: INCA, 2002. p. 17-37.

45. Ministério da Saúde. Projeto SB Brasil 2003: condições de saúde bucal da população brasileira 2002-2003. 1a. ed. Brasília, 2004.

46. Miotto NML, Holderbaum RM, Figueiredo MAZ. Glossite rômbica mediana. Rev Bras Patol Oral, 2003 jan/mar;2(1):19-26. 
47. Miotto NML, Yurgel LS, Cherubini K, Cazanova RF. Métodos laboratoriais de identificação do fungo Candida sp. Rev Fac Odontol Passo Fundo, 2004;9(1):27-33.

48. Morimoto K, Kihara A, Suetsugu T. Clinico-pathological study on denture stomatites. J Oral Reahbil, 1987;14:513-22.

49. Newton AV. Denture sore mouth. Brit Dent J, 1966;1(112):35760.

50. Noronha L, Medeiros F, Sepulcri RP, Neto JF, Bleggi-Torres LF. Manual de dermatologia, 1a ed. Curitiba, 2000.

51. Nyquist $\mathrm{G}$. The influence of denture hygiene and the bacterial flora on the condition of the oral mucosa in full denture cases. Acta Odont Scand, 1953 Jul;11(1):24-61.

52. Odell EW, Morgan PR. Non-dysplastic and white lesions of the oral mucosa. In: Biopsy pathology of the oral tissues. 1a ed. London: Chapman \& Hall Medical, 1998. p. 151-181.

53. Oliver DE, Shillitoe EJ. Effects of smoking on the prevalence and intraoral distribution of Candida albicans. J Oral Pathol, 1984 Jun;13(3):265-70.

54. Pinto A, De Filippi R, Frigeri F, Corazzelli G, Normanno N. Aging and the hematopoietic system. Crit Rev Oncol Hematol, 2003 Oct;48(Suppl):3-12.

55. Rautemaa R, Ali A, Hietanen J, Jarvensivu A, Richardson M, Konttinen YT. Expression of intreleukin-8 and its receptor IL-8R in chronic hyperplastic candidosis. Oral Microbiollmmunol, 2006 feb;21:223-30. 
56. Razek MKA, Shaaban NA. Histochemical and histopathologic studies of alveolar mucosa under complete dentures. J Prosthet Dent, 1978;39:2939.

57. Reeve CM, Roekel NBV. Denture sore mouth. Dermatol Clin, 1987;5(4):681-86.

58. Reichl RB. Oral candidosis: an old disease of growing concept. Gen Dent, 1990 March-April;114-20.

59. Rossie KM, Taylor J, Beck FM, Hodgson SE, Blozis GG. Influence of radiation therapy on oral Candida albicans colonization: a quantitative assessment. Oral Surg Oral Med Oral Pathol, 1987 Dec;64(6):698-701.

60. Silverman SJr, Luangjarmekorn L, Greenspan D. Occurrence of oral candidosis in irradiated head and neck cancer patients. J Oral Med, 1984 OctDec;39(4):194-96.

61. Ten Cate AR. Mucosa bucal. In: Histologia Bucal: desenvolvimento, estrutura e função. 5a ed. Rio de Janeiro: Guanabara Koogan; 2001. p. 323-59.

62. Tsuchiya H, Hoshino Y, Tajima K, Takagi N. Leaching and cytotoxicity of formaldehyde and methyl methacrylate from acrylic resin denture base materials. J Prothet Dent, 1994;71(6):618-24.

63. Vitkov L, Krautgartner WD, Hannig M, Weitgasser R, Stoiber W. Candida attachment to oral epithelium. Oral Microbiol Immunol, 2002 Fev;17(1):60-4.

64. Vitkov I, Weitgasser R, Hanning M, Fuchs K, Krautgartner WD. Candida-induced stomatopyrosis and its relation to diabetes mellitus. J Oral Pathol Med, 2003 Jan;32(1):46-50. 
65. Waltson B, MacDonald DG. Oral mucosa and complete dentures. J Prosth Dent, Feb, 1982;47(2):133-40.

66. Wictorin L, Anneroth G, Frithiof L. Denture stomatitis: a clinical, electron-microscopic, microradiographic and light-microscopic study. Acta Odontol Scand, 1975;33(5):299-311.

67. Williams DW, Potts AJC, Wilson MJ, Matthews JB, Lewis MAO. Characterisation of the inflammatory cell infiltrate in chronic hyperplastic candidosis of the oral mucosa. J Oral Pathol Med, 1997;26:83-9.

68. Yamamoto $\mathrm{Y}$, Klein TW, Friedman $\mathrm{H}$. Involvement of mannose receptor in cytokine interleukin-1beta (IL-1beta), IL-6, and granulocyte-macrophage colony-stimulating factor responses, but not in chemokine macrophage inflammatory protein 1beta (MIP-1beta), MIP-2, and KC responses, caused by attachment of Candida albicans to macrophages. Infect Immun, 1997 Mar;65(3):1077-82 
ABSTRACT 



\title{
CANDIDOSIS ASSOCIATED WITH THE USE OF MAXILLARY COMPLETE DENTURE: DEMOGRAPHIC, CLINICAL AND MICROSCOPIC EVALUATION.
}

\begin{abstract}
Denture stomatitis is an inflammatory process affecting the oral mucosa in contact with acrylic resin of complete dentures or removable partial dentures. The disease has a multifactorial etiology, associate with local and systemic factors, including the presence of Candida albicans. The present study aimed to conduct a demographic, clinical and microscopic analysis of candidosis associated with the use of maxillary complete denture, in both atrophic and papillary hyperplastic forms and associated with inflammatory fibroepithelial hyperplasia. For that purpose, specimens from the files of the Anatomical Pathology Laboratory at the Department of Stomatology, Bauru Dental School, University of São Paulo, were microscopically reviewed in sections stained with hematoxylin and eosin (HE), Grocott's methenamine silver and periodic acid-Schiff (PAS), and compared to normal palatal tissues obtained from non-denture wearers. Clinical information was obtained and selected from clinical records. Regardless of the group, the specimens of oral candidosis were mainly obtained from aged individuals, with average age of 51 to 60 years, especially females and white individuals. In some cases, the clinical diagnosis of the atrophic denture stomatitis can be difficult and requires biopsy for confirmation. Papillary hyperplasia lesions are removed more frequently than atrophic denture stomatitis lesions, since they are generally recognized by clinicians as inflammatory fibroepithelial hyperplasia. Candidosis in inflammatory fibroepithelial hyperplasia does not present exclusive clinical signs of its presence; thus, clinical suspicion of this association is improbable. Different from the normal mucosa, microscopically, most cases of oral candidosis present hyperplastic epithelial lining with elongated rete pegs, some with "test tube" aspect, with frequent areas of absence of keratin, small foci of lichenoid reaction and microabscesses, as well as extensive areas of pseudoepitheliomatous hyperplasia. Only papillary hyperplastic lesions exhibited bifid rete pegs, besides high frequency of keratin pearls-like and long "test tube" rete
\end{abstract}


pegs, when compared with the other forms of oral candidosis. The connective tissue underlying the oral candidosis presented moderate to intense mononuclear inflammatory infiltrate, predominantly at the lamina propria and perivascular region. Fungal hyphae and yeasts were not identified by special staining with Grocott's methenamine silver and (PAS). Thus, the microscopic diagnosis of oral candidosis should not depend on the visualization of fungal hyphae and yeasts at the most superficial layers of epithelial lining.

Keywords: candidosis, maxillary complete denture, denture stomatitis. 